Portland State University

PDXScholar

3-1-2018

\title{
Do Internal or External CSR Strategies Yield Higher Social and Financial Returns?
}

\author{
Emily Lundberg \\ Portland State University
}

Follow this and additional works at: https://pdxscholar.library.pdx.edu/honorstheses

\section{Let us know how access to this document benefits you.}

\section{Recommended Citation}

Lundberg, Emily, "Do Internal or External CSR Strategies Yield Higher Social and Financial Returns?" (2018). University Honors Theses. Paper 550.

https://doi.org/10.15760/honors.556

This Thesis is brought to you for free and open access. It has been accepted for inclusion in University Honors Theses by an authorized administrator of PDXScholar. Please contact us if we can make this document more accessible: pdxscholar@pdx.edu. 


\section{Abstract}

In the last decade, there has been a revolution in the perception of businesses as entities whose sole goal is to yield returns for their shareholders to the belief that they have a responsibility to mitigate their negative impacts on communities and the environment by voluntarily taking actions to improve those entities. Though there is an increased emphasis among businesses on corporate social responsibility (CSR), there is limited research examining how companies can maximize the positive impact of their strategies and whether or not investing in doing so will make them more successful. To address this gap, my thesis will attempt to answer the question: Do internal or external CSR strategies yield higher ROIs for both companies and the causes they seek to support? By analyzing eight hundred and thirty-nine CSR strategies from ten companies, the study found that internal strategies are significantly more effective than external strategies. The researchers were unable to come to a conclusion regarding the financial ROI of strategies due to limitations in the available financial data and difficulty in comparing data between companies of different industries.

\section{Introduction}

Between 2011 and 2016, the number of S\&P 500 companies who published sustainability reports rose from twenty percent to eighty-two percent, signifying a rapidly growing commitment from publicly traded companies to investing sustainability (Flash Report, 2016). The dramatic rise in 
corporate social responsibility (CSR) over the last decade is not predominantly fueled by business executives' desires to make a positive impact but rather by society's demands that they do so. In a capitalist economy, businesses are bound by a social contract to respond to society's needs or cease to exist and thus, the evolution of corporate social responsibility has been driven by society's expectation of business (Arena et al.). According to the 2015 Nielsen Global Sustainability Report, sixty-six percent of global consumers and seventy-three percent of millennials are willing to pay more for environmentally sustainable products (Nielsen, 2015). It is not just environmental sustainability that consumers care about. The 2015 Cone Communications CSR study found that eighty-seven percent of Americans are more willing to purchase from companies who support the same causes they do and seventy-six percent refuse to purchase from companies if companies take actions that contradict their beliefs and alternative products are available (Cone Communications, 2015).

Investors are consumers, too, and the preference for socially and environmentally responsible companies has led to a rise in socially responsible investing in which investors give preferences to stocks from companies that have demonstrated they make a positive impact. As of the end of 2015 , over twenty percent of professionally managed stocks were traded in alignment with socially responsible investing guidelines (The Forum for Sustainable and Responsible Investment). That percentage marks a 33\% increase since 2014 and it is expected to continue to rise (The Forum for Sustainable and Responsible Investment). Thus, the rise in socially aware consumers coupled with the rise in socially responsible investing has made investing in CSR a strategic necessity. 
It is not just public companies that have raced to prove their commitment to social and environmental responsibility. Private companies have also recognized the need to adopt CSR practices and the most powerful example of this is the rise of B-corps. B-corps were created in 2006 by the nonprofit B Lab to give businesses the opportunity to have third party certify that they are making a positive impact (Our History $\mid$ B Corporation). The organization provides businesses with a detailed assessment to test how socially and environmentally their business practices are. Following the assessment, companies are given a series of scores and recommendations for improvement (Measure What Matters Most $\mid$ B Impact Assessment). Every company's B-corps assessment scores are publicly available online to allow consumers to see how well a company's actions align with the causes they are passionate about. Though not required, many B-corps such as Ben and Jerry's and New Seasons Market (both included in this study) also publish CSR reports like public companies do.

As consumers and businesses have become more interested in CSR, so have researchers. The Academy of Management Journal and many others published record numbers of articles about CSR between the 2000s and 2010s years ("Corporate Social Responsibility Feature"). Despite the additional research, academics have yet to decide on a unified definition of corporate social responsibility.

For the purpose of this project, corporate social responsibility will be defined as companies' "need to ensure healthy ecosystems, social equity and good organizational governance," based on the ISO 26000 corporate social responsibility guidelines (ISO 26000). In addition to the definition, an even less explored gap in the research is what qualities constitute an effective CSR 
strategy both in regards to how well strategies create the promised social and/or environmental impact and the extent to which having effective CSR strategies is associated with financial success. To address this gap, my thesis will attempt to answer the question: Do internal or external CSR strategies yield higher ROIs for both companies and the causes they seek to support? For the purposes of this project, internal strategies will be defined as decisions companies make regarding their products, processes, policies and facilities that contribute to environmental sustainability, social equity and ethical governance. External strategies will be defined as investments the company makes to support causes outside of their business typically through donations of money, products, services and employee time. In total, a mix of eight hundred and thirty-nine internal and external strategies were gathered from ten companies to answer this question.

\section{Methodology}

To test whether internal or external CSR strategies yield higher social and financial returns, the researcher reviewed the CSR strategies of the following five public companies and five B-corps:

\begin{tabular}{|l|l|}
\hline Public Companies & B-corps \\
\hline $3 \mathrm{M}$ & AllCare Health \\
\hline Intel & Ben and Jerry's \\
\hline
\end{tabular}




\begin{tabular}{|l|l|}
\hline Nike & New Seasons Market \\
\hline Starbucks & Patagonia \\
\hline Walmart & Seventh Generation \\
\hline
\end{tabular}

The above companies were chosen because they have demonstrated a long-term commitment to corporate social responsibility and have taken actions in their company structures, policies and marketing to make CSR an integral part of their companies. Additionally, they represent a variety of industries which opens up the possibility of additional analysis opportunities if there are trends among companies in similar industries or if industry does not appear to play a role in the results. Both public companies and B-corps were included in this study to see if there is a difference in the types of CSR strategies that public companies versus private companies use and to determine if the ways both types of companies implement their strategies would lead to different score trends. Furthermore, B-corps were chosen as the form of private company because they have a proven commitment to being socially responsible and thus there is more publicly available information about their CSR strategies than a typical private company.

The strategies for the public companies were sourced from their CSR reports from 2011-2017 with slight variations based on availability. While reviewing the reports, the researcher gathered every single strategy listed and categorized it as internal or external based on the definitions provided in the previous section. Not all of the B-corps studied publish formal corporate social responsibility reports so, for the ones that do such as Ben and Jerry's, the process for gathering 
CSR strategies was identical to the process for public companies. However, for the companies such as Patagonia who have a less formal reporting process, various sections of their website and articles from non-company affiliated websites were used to source strategies. After compiling the initial list of strategies for all of the companies, the researcher removed duplicate strategies which mostly included strategies that were implemented over the course of multiple years.

The following chart shows the number of internal, external and total strategies compiled from each company after duplicates were removed:

\section{Total Number of Strategies by Company}

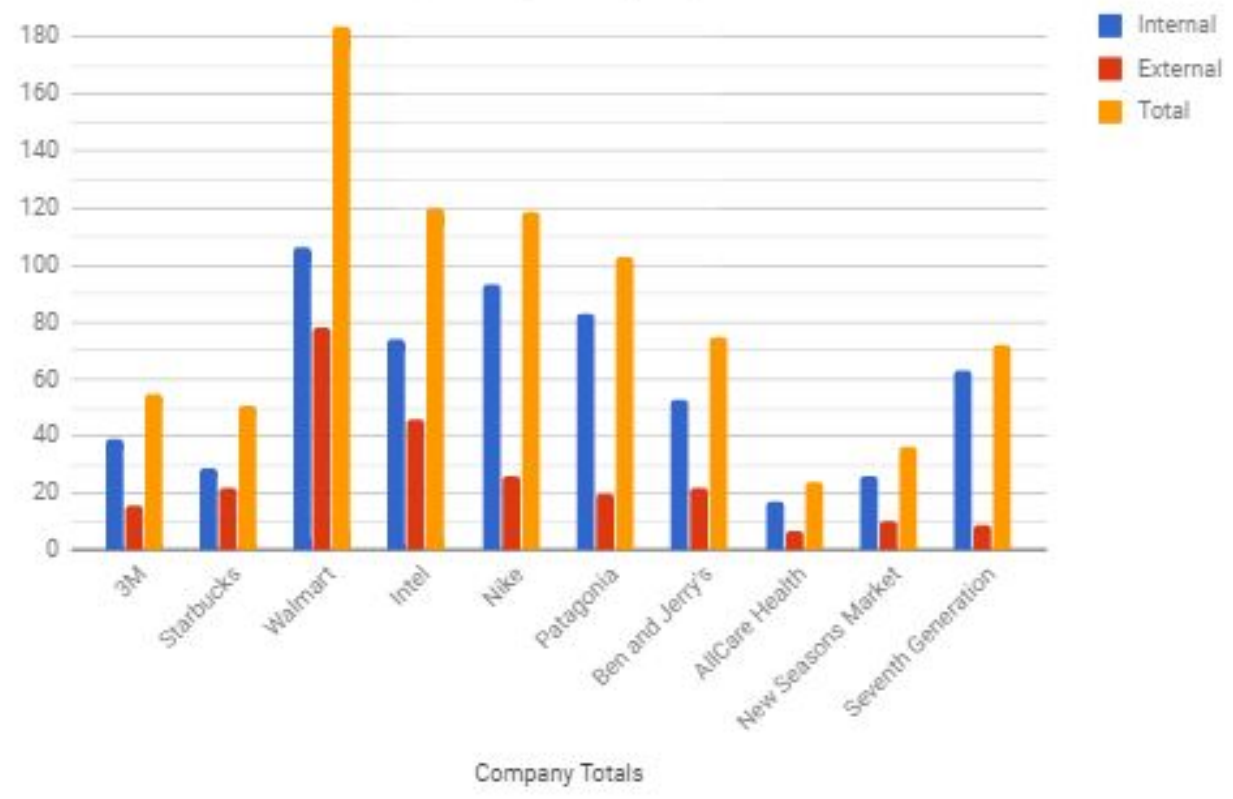


The total number of strategies gathered from all companies was eight hundred and thirty-nine. It is apparent that all companies had a significantly higher quantity of internal strategies compared to external. There are three primary reasons for this:

1) Overall, companies reported fewer external strategies.

2) Many companies opt to sum up their external strategies with a few statements such as "We donated 1 million dollars to hunger relief, " or "Our employees volunteered 400,000 hours." Within those statement are likely an unknown number of additional smaller strategies that could not be accounted for.

3) The researcher chose to count strategies that were identical in all characteristics but their names as single strategies. This decision applies to both internal and external strategies however, it had a greater effect on the quantity of external strategies because more of the strategies in this category qualified to be grouped as single strategies. For example, Patagonia listed every dozens of environmental organizations they donated to however, the researcher chose to count donating to environmental organizations as a single strategy. The researcher did this because donating to each organization would have yielded the same score thus, when averaged, would not have affected Patagonia's overall score.

To assess the effectiveness of each strategy, the researcher created an assessment tool to score each strategy on a scale of $0-10$. The tool contains the following five factors that are based on what the research determined were the top characteristics that ensure CSR strategies have a 
positive impact on the causes they are trying to help and have the potential to yield higher financial returns for the company:

1) Aligns with the business's core competencies

2) Has measurable performance

3) Demonstrates a long-term commitment to the underlying cause

4) Benefits primary stakeholders

5) Has innovative qualities

Below are explanations of why each factor was chosen and some additional criteria that was used to assess strategies based on each factor:

\section{Aligns with the Business's Core Competencies}

Core competencies are "a unique ability that a company acquires from its founders or develops and that cannot be easily imitated. Core competencies are what give a company one or more competitive advantages, in creating and delivering value to its customers in its chosen field. (Do you know this term?)." Alignment with core competencies was chosen as a factor because it defines the ways that each business has proven to be capable in generating positive value.

This was considered important to evaluate for three reasons:

1) It helps to mitigate the influence of greenwashing on the overall scores. Evidence shows that greenwashing in the United States has skyrocketed since the mid-2000s due increased consumer preferences for products that have a minimal negative impact on the 
environment (Delmas and Burbano). A Nielsen study also found that sixty-six percent of global consumers are willing to pay premiums for products from socially responsible brands. The rise in consumer demand for socially and environmentally responsible products incentivises companies to make their companies appear more responsible than they are which is why greenwashing and the social equivalent has become so prevalent. Since core competencies are skills that the business excels at, it is more likely that CSR strategies that fall within them make the suggested impact and are not used solely as marketing tactics.

2) It limits the influence of strategies that unintentionally harm communities due to a business's ignorance about the cause they are trying to support. The documentary Poverty Inc. covers the often hidden negative impacts of businesses and other institutions entering impoverished countries and trying to solve their problems. They described several examples of big businesses harming communities by providing aid, either independently or via non-profits and non-governmental organizations, that did not taken into consideration the specialized needs of local economies and cultures. Instead, businesses' CSR strategies were based on a paternalistic approach in which those with money and power attempt to save those without it by forcing impoverished groups to accept what the company wants to give as opposed to what they actually need ("Poverty, Inc."). When entities attempt to help causes that they are not well-informed about it can drastically reduce the effectiveness of their efforts. A prime example of this comes from a study published by researchers at Rensselaer Polytechnic Institute; they found that fifty to 
seventy percent of goods donated for disaster relief end up in landfills because entities make donations without understanding what victims actually need (Holguín-Veras et al.).

3) Strategy alignment with a business's core competencies is associated with increased positive consumer opinions of businesses and their strategies (García-Jiménez et al.). That finding was largely due to the fact that consumers are less skeptical of the motives and effectiveness of strategies that are directly tied to businesses. This is critical because for CSR strategies to give companies a competitive advantage, consumers must believe companies genuinely care about the causes they are supporting and are supporting them in effective ways.

When determining what each company's core competencies are, the researcher considered the term broadly as the definition suggests one should. Nike, for example, has entered the technology market with fitness apps and wristbands to help their customers track and optimize their athletic performance (Carr). This strays beyond their surface-level core competency of creating athletic shoes and apparel but fits within their overall core competency of producing athletic products.

Examples of strategies that align with core competencies include Patagonia's use of environmentally sustainable fabrics which aligns with their core competency of producing environmentally-friendly products and $3 \mathrm{M}$ developing innovative solutions to improve healthcare which aligns with their innovation-driven core competency. Strategies that scored a two aligned well with their company's core competencies, strategies that scored a one were 
somewhat related to them and strategies that scored a zero had nothing to do with a company's core competencies.

See Appendix A for a list of each company's core competencies.

\section{Has Measurable Performance}

Ensuring that the impact of strategies can be measured is critical because it is the only way to determine if a CSR strategy is worth the investment (Epstein and Yuthas). Having a measurable impact is also critical for ensuring that companies are held accountable for making the positive impact that they say they are. There are a variety of ways that a strategy's performance can be measurable. The first is that a company included a statistic along with their strategy to prove its impact. For example, "reduced energy usage in factories by $12 \%$." Other ways include having regular audits to track progress and/or ensure strategy implementation, the ability to be tracked over the lifetime of the company investment in the strategy and any other way that a strategy can be quantified to give companies indicators of whether or not strategies were effective. Based on measures of what strategies are more effective than others, companies can revise their CSR plans to ensure their budgets are being put towards activities that make the biggest impact.

To score a two on this factor, strategies had to be explicitly measureable. To score a one, it could be reasonably assumed that the strategy could be measured and strategies that scored a zero had little to know way to measure their impact. 


\section{Demonstrates a Long-Term Commitment to the Underlying Cause}

The purpose of corporate social responsibility is to use business to help social and environmental problems - regardless of motivation for doing so. It's impossible to solve a major problem with a single donation, activity, product etc. Making an impact requires long-term efforts (Keys et al.). Additionally, the World Economic Forum has found that CSR strategies can only make a significant impact if companies invest time in learning about the causes they intend to support and continuously make improvements to the ways they offer help ("How to Fix Corporate Social Responsibility"). This factor assesses whether strategies are complete the moment they are finished being implemented or whether they are formed in a way that the business can continuously improve upon it. It also considers whether the impact of the strategy is long or short-term. Some strategies such as food donations immediately solve problems like hunger but only until the donations run out. Donating food does not address the underlying long-term poverty issue that is causing hunger. Contrastingly, donations such as wells or designing buildings to meet strict environmental standards yield benefits for several years.

Strategies that demonstrate long-term commitment to causes are also critical in building businesses reputations as responsible companies. Brief, one-time strategies are often barely noticed and forgotten but, when companies consistently demonstrate their commitment to creating positive change, it allows them to yield the benefits of being recognized as a socially responsible company. The benefits companies receive come from customers, employees and governments. As previously noted, sixty-six percent of global consumers are willing to pay more for products from socially responsible companies (Nielsen, 2015). Also, most employees love 
working for companies who care about the same causes they do which leads socially responsible companies to have up to $15 \%$ higher employee productivity and up to $50 \%$ lower turnover (Latter). Additionally, long-term strategies relating to reducing environmental impacts and improved employee treatment (including contract workers) enables companies to stay ahead of government regulations and avoid potential fines later on if they are unable to adapt quickly enough to stricter policies (Carroll and Buchholtz).

To score a two on this factor, strategies had to explicitly be implemented and make an impact over an ongoing period of time as opposed to a short-term, fixed period of time. To score a one, the strategy could have been reasonably assumed to be long-term, though it was not explicit. Strategies that scored a zero were implemented for a fixed period of time and had a short-term impact.

\section{Benefits Primary Stakeholders}

One of the most fundamental principles of corporate social responsibility is that companies need to act in the best interests of their stakeholders. Since primary stakeholders are those whom are directly impacted by businesses, companies must serve them to be considered socially responsible. A business's primary stakeholders are: shareholders and investors, employees, customers, local communities, suppliers and other business partners, the natural environment, future generations, nonhuman species (Carroll and Buchholtz). This strategy was included in the assessment tool because engagement with stakeholders gives companies a competitive advantage 
and is correlated with their financial success (Laughland). Thus, the payoff from these strategies enables companies to financially justify continuing invest in corporate social responsibility.

To score a two, a strategy had to benefit one or more of the aforementioned stakeholder groups. A one score indicates either that the benefits to a primary stakeholder are ambiguous or that it is not completely certain if the entities benefitting from the strategy are the primary stakeholders.

\section{Has Innovative Qualities}

The OECD, a think-tank for rich countries, says innovation can be defined as "new products, business processes and organic changes that create wealth or social welfare (Something New under the Sun | The Economist)."

The key elements the researcher pulled from that definition are:

- New (new to the company, one cannot expect every company to come up with completely original strategies)

- Creates wealth (cost-savings or revenue)

- Creates social welfare (benefits entities beyond the company)

Innovation is critical to the effectiveness of CSR strategies because, according to the documentary Poverty Inc. the aid industry, which includes nonprofits, social entrepreneurs, independent philanthropies and any other individual or group that strives to provide aid to those in poverty, is hindering the growth of impoverished communities by continuing to base many 
strategies off of the paternalistic aid model that was created to help aid Europe's recovery from World War II via the successful Marshall Plan (“Poverty, Inc.”). That model has been proven to be outdated and companies need to innovate new methods of social responsibility in order to be effective.

Developing innovative CSR strategies also plays a role in companies' ability to harness CSR as a competitive advantage. As of $2016,81 \%$ of S \& P 500 companies publish CSR reports (FLASH REPORT). For a company's CSR strategies to stand out in marketing campaigns, companies will likely need to differentiate themselves from their competitors. B-corps are also under this pressure because their CSR strategies can be the only competitive advantages that set them apart from other companies who offer very similar products.

To score a two, strategies had to fully match at least one of the elements of the innovative definition, to score a one strategies had to be somewhat innovative and, to score a zero the strategy was not at all innovative.

\section{Assessment Tool}

Using these strategies, the researcher created the following assessment tool. Each strategy was given a score of zero, one or two for each factor. Zero means the strategy does not fulfill the factor's requirements, one means that it somewhat does and two means that the strategy fully fits the factor. 


\begin{tabular}{|l|r|}
\hline Assessment Tool: Denim Jeans are & \\
\hline Fair-Trade Certified for Sewing & Example \\
\hline Factors & Scores (0-2) \\
\hline Aligns with Core Competencies & 2 \\
\hline Has Measurable Performance & 2 \\
\hline Demonstrates a Long-Term Commitment & \\
\hline Benefits Primary Stakeholders & \\
\hline Has Innovative Qualities & 0 \\
\hline Total & 7 \\
\hline
\end{tabular}

Due to the substantial variation in the quantity of strategies implemented by each company, all of the scores were averaged within their categories to yield comparable results corresponding to the assessment tool's zero to ten scale.

\section{Results}

The study found that in every category internal strategies scored significantly higher than external strategies. Below are the end findings:

\section{Overall Findings}




\begin{tabular}{|l|c|}
\hline Public Internal Average & 7.46 \\
\hline Public External Average & 4.45 \\
\hline B-Corp Internal Average & 8.32 \\
\hline B-Corp External Average & 5.25 \\
\hline Overall Internal Average & 7.83 \\
\hline Overall External Average & 4.67 \\
\hline Overall Public Average & 6.41 \\
\hline Overall B-Corp Average & 7.67 \\
\hline
\end{tabular}

For public companies, internal strategies scored $40.4 \%$ higher than external strategies. Among B-corps, internal strategies scored $36.9 \%$ higher than external strategies and, overall, internal strategies scored $40.4 \%$ higher than external strategies. Another interesting finding is that B-corps strategies scored overall $16.4 \%$ higher than public company strategies. Beginning this study, the researcher was not sure what to expect regarding the differences between B-corps because the large, public companies in this study have far greater financial resources yet, the results reveal that the accountable commitment B-corps have to being socially and environmentally responsible ensures that they invest their limited CSR funds in ways that make a greater impact.

Below is a graphical display of the data just described: 


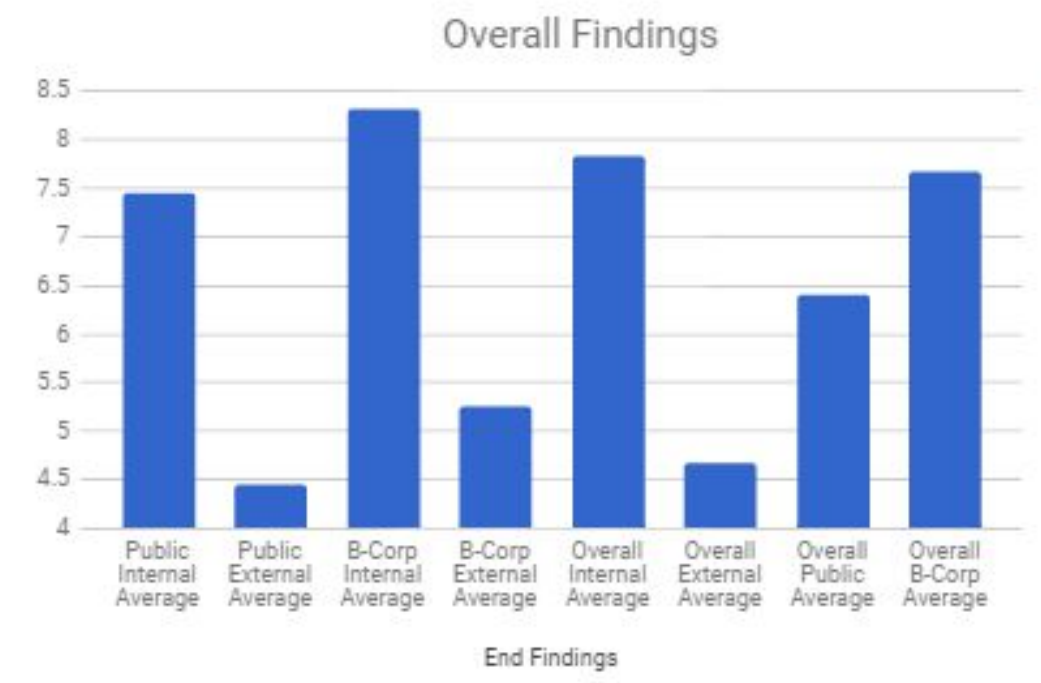

Below are the average internal, external and overall results from every company:

\section{Company Internal, External and Overall Averages}

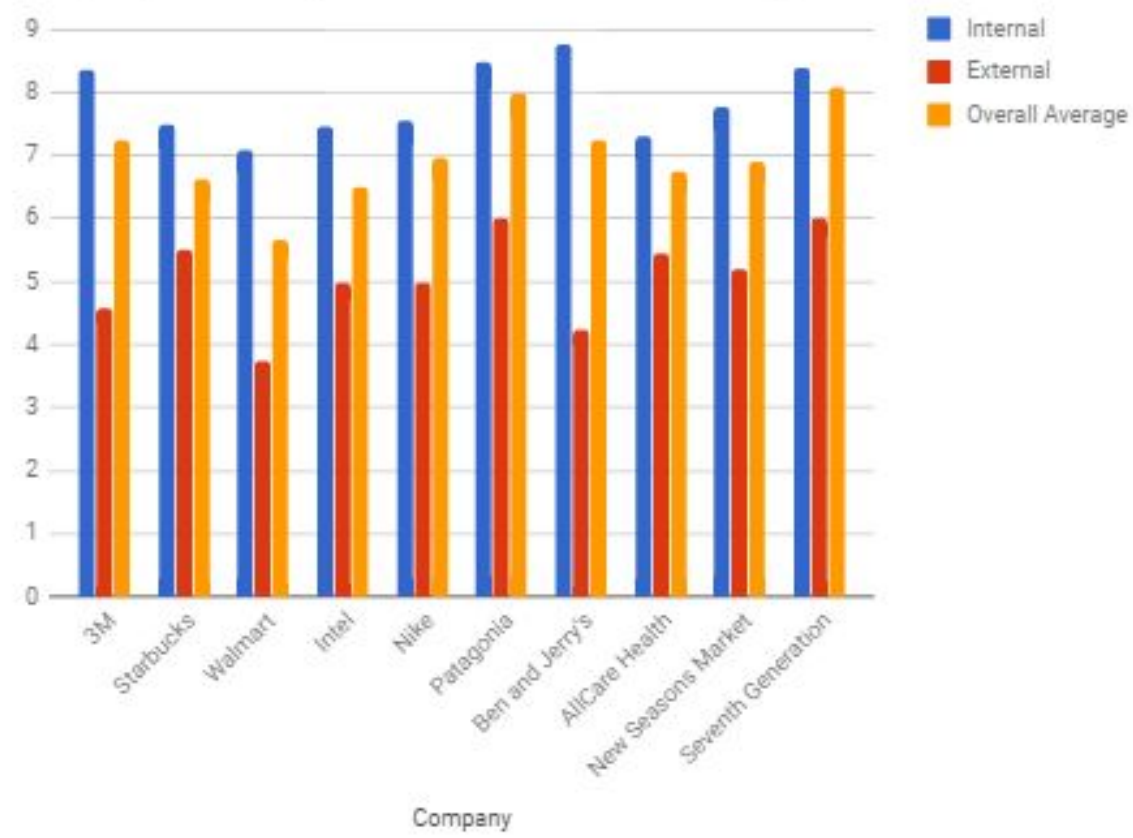

This graph shows that there is no significant difference in the categorical distribution of results between public companies and B-corps and that in every case internal strategies scored higher. 
The effectiveness of internal strategies compared to external strategies was not the result of a outliers that skewed the averages. The following graph shows the highest and lowest internal and external scores for each company. In the case of every single company, the internal high and low scores exceeded the external scores which reveals that the characteristics of internal strategies enable them to be more effective.

\section{Company Internal and External Highs and Lows}

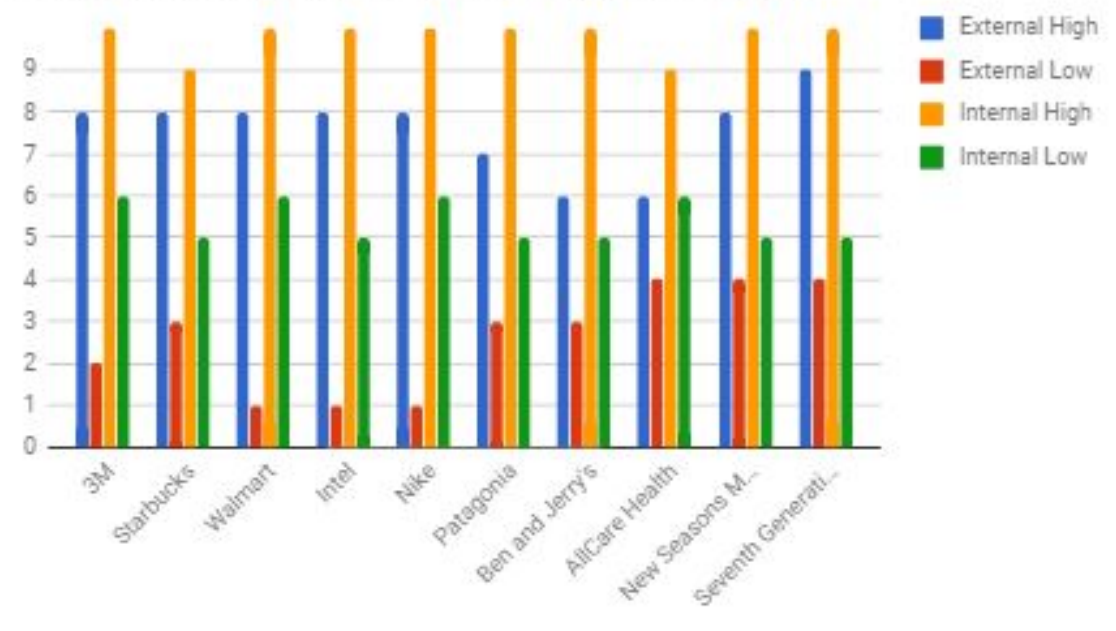

\section{Financial Results}

When planning this project, the researcher intended to attempt to see if there is an association between the companies with the highest scores and their financial success. After researching potential options to evaluate and compare the financial data from the companies in the study it was determined that the variation of industries included combined with the lack of comparable financial information available for the B-corps would make it nearly impossible to accurate results ("Comparing Financial Ratios Between Industries"). Further research should analyze 
multiple companies within the same industry to see if there is a connection between strategy effectiveness and financial success.

\section{Discussion and Further Research}

This study revealed that, on average, internal CSR strategies are more effective than external ones. The implication of that finding is that companies should invest most of their CSR budgets into internal strategies. A benefit of this finding is that justifies decisions to invest more resources into improving companies which likely leads to a higher financial return on those strategies.

Throughout the study, the researcher has referred to CSR strategies in general terms but has not illustrated why certain strategies are more or less effective based on the assessment tool. The following section analyzes the top four companies and the bottom three companies to highlight some of the most and least effective strategies scored in this study.

\section{Analysis of the Top Three Companies}

The companies with highest average scores were Seventh Generation (avg. 8.07), Patagonia (avg. 7.99) and 3M (avg. 7.25). Ben and Jerry's was a close fourth with an average score of 7.23. The following analysis of those companies will illustrate some of the ways that companies can implement highly effective CSR programs. 


\section{Seventh Generation}

Seventh Generation is a B-corp that produces environmentally-friendly cleaning supplies and other home products. They excelled thanks to their focused corporate social responsibility vision, innovative approaches and commitment to developing strategies that have a long-term impact. As a producer of safer, more environmentally-friendly products, the company had an advantage in that much of its daily operations can be represented as high-scoring CSR strategies due to the positive impact and measurable impacts their products have on primary stakeholders. The company must also continuously innovate their products to become more environmentally-friendly in order to maintain their competitive advantage as other companies mimic their formulas and approaches.

Beyond creating socially and environmentally responsible products, Seventh Generation also strives to increase its sustainability by making it one of the company's top priorities. A unique way the company does this is with a self-imposed carbon tax. For every ton of carbon the company emits, it dedicates a portion of revenue toward sustainability projects that will help the company achieve its long-term goal of becoming carbon neutral. This strategy is remarkable because it directly ties the negative environmental impact the company has to their efforts to reduce that impact and it limits the company from reducing their CSR budget during during difficult economic times.

\section{Patagonia}


Like Seventh Generation, Patagonia, an outdoor apparel company, scored well largely due to its commitment to producing environmentally-friendly products by placing many socially and environmentally responsible restrictions on their supply chain. There are three primary qualities that set Patagonia apart from the others included in this study. The first is that their products are built to last for many years and they offer free repairs to even further extend their product lives. This allows them to reduce the impact of their entire product life cycle since fewer of their products end up in landfills. Their second differentiator is that their CSR marketing strategy focuses on education not promotion. The company is fervently against greenwashing so, rather than point out the generic environmental benefits of their features, they use specific language and teach consumers why their material choices and other decisions make a positive impact. Not only does educating consumers, help them gain trust but it also gives consumers knowledge to make more informed purchasing decisions for items beyond Patagonia products. The third characteristic that made their CSR strategies great is that nearly all of their external strategies aligned with their core competencies which allowed them to score fair on that factor and the benefiting primary stakeholders factor.

\section{$3 \mathbf{M}$}

As a manufacturing company who produces over 55,000 products for a wide range of industries, 3M's core competencies does not appear directly inspire the company to develop a highly effective CSR program. However, they were able to do so because they are an innovative company full of scientists who are continuously making long-lasting innovations to improve the environmental sustainability of their operations. Similarly, their need to attract top talent that 
enables them to maintain their competitive advantage also drives them to implement strong diversity-focused and other beneficial hiring and employment policies.

\section{Ben and Jerry's}

Since Ben and Jerry's was only .2 away from being in third place, the researcher also wanted to acknowledge some of the strategies that enabled the company to score highly. Though all of the companies in this study have strategies to improve the responsibility of their supply chains, Ben and Jerry's efforts stand out because not only do they source from sustainable suppliers, they also have robust initiatives to help their suppliers become more socially and environmentally responsible. Their initiatives include: helping their suppliers become B-corps, a Caring Dairy plan that educates and certifies dairies, promoting B-corp suppliers such as a bakery that hires and provides job training to "unemployable" people among many other strategies. By helping their suppliers improve their own CSR strategies, Ben and Jerry's extends their impact beyond their own operations and CSR investments.

\section{Analysis of the Bottom Three Companies}

The companies with the lowest average scores were Starbucks (avg. 6.63), Intel (avg. 6.5) and Walmart (avg. 5.67). The following analysis of those companies will highlight why those companies' strategies lacked effectiveness so that other companies can avoid implementing the same types of strategies.

\section{Starbucks}


Scoring less than a point under Ben and Jerry's, Starbucks CSR strategies are far from terrible but, the company does have much room for improvement. The predominant weakness in their strategies was a lack of innovation. Rather than seeking ways to reinvent CSR in their industry, the company focused heavily on widespread strategies such as ethical sourcing and partnering with industry organizations and nonprofits. Those strategies do have a positive impact but, they do little to increase the rate at which social and environmental problems are being solved. It should also be noted that Starbucks' average score may be artificially low due to the small amount of strategies listed in their CSR reports. Rather than explicitly state many of their strategies, they used broad strategies that likely encompassed many strategies that could have scored higher if they were listed.

\section{Intel}

Intel's weaknesses revolved around a lack of innovation in both their internal and external CSR strategies and a lack of alignment with core competencies and benefits for primary stakeholders among their external strategies. While the company earned some internal ten scores for highly innovative and impactful strategies such as inventing a bangle that will alert women in India of dangerously high levels of carbon monoxide, they also documented some less innovative and impactful internal strategies such as hosting sustainability speakers and providing sustainability training for managers. Among their external strategies were a few that, on top of lacking innovation, had no connection to their core competencies or primary stakeholders and those negatively impacted the company's average score. 


\section{Walmart}

Despite documenting one hundred and eighty-four strategies, sixty-four more than Intel - the company with the next highest quantity, Walmart had the worst average score by approximately a 10\% margin. The factors that Walmart's strategies scored the lowest on were "Has Innovative Qualities," "Aligns with Core Competencies" and "Benefits Primary Stakeholders." External strategies scored particularly low on the latter two because Walmart makes donations to a lot of different entities who are not primary stakeholders and both cash and in-kind donations receive a zero on the innovation factor. Generally, Walmart's strategies lacked driving forces and combined with the large quantity of strategies gives the impression that the company's CSR program seeks to lightly benefit as many areas as possible so that they can earn positive press but fails to invest enough strategic effort into their strategies to make a lasting and innovative impact on their primary stakeholders.

\section{Additional Considerations}

In addition to determining whether internal or external CSR strategies are more effective, the researcher also sought to explore was the difference in strategy effectiveness between public companies and B-corps. As revealed in the results section, B-corps scored on average 16.4\% higher than public companies despite having far less financial resources to invest in CSR. B-corp strategies likely score so much higher because, by definition, B Corps meet the highest standards of verified social and environmental performance, public transparency, and legal accountability (Why B Corps Matter | B Corporation).” The strict third-party review that they periodically undergo forces them to develop strategies that make a proven impact. Though some public 
companies hire third party companies to audit portions of portions of their internal strategies and/or their their CSR reports, those audits do not necessarily look at the quality of the strategies, instead they focus on the accuracy of reporting and the extent to which actions are being taken to implement proposed improvements, particularly in the supply chain. (Björkman and Wong).

\section{Limitations and Suggestions for Further Research}

A major limitation in this study is that the researcher relied solely on publicly available information. This affected the data that was collected in two primary ways. The first is that it is unknown what percentage of CSR strategies that each company chose to explicitly disclose. Strategies may have been excluded from CSR reports and other publications for reasons including companies believing they are not of interest and/or understandable to stakeholders and companies clumping many strategies under single, broad statements. The latter appeared particularly prevalent especially when one considerations the variation in the quantity of strategies between certain companies.

3M's CSR reports were approximately two hundred pages each and yet their reports only yielded fifty-five strategies. Comparatively, Intel's CSR reports were approximately one hundred pages each, about half the length of $3 \mathrm{Ms}$, and yet they yielded one hundred and twenty strategies. The length of 3M's reports does not reflect the quantity of documented strategies because, rather than detailing every single strategy they implemented, the company went into great depth into the why and the how of specific strategies. Likewise, Starbucks generalized many of their strategies under large strategies such as making their stores LEED certified and emphasizing 
Fair-Trade and their Global Farmer Fund to cover what they are doing to improve social welfare in their supply chain. It takes several environmental improvements to become LEED certified and their Global Farmer Fund provides a variety of services for farmers and, had each of those strategies been broken down, the company would have had many more strategies to score.

The second limitation of using solely publicly available data is that any information that a company chooses to publish is influenced by their marketing agenda. Thus, companies will only publish information that directly contributes to the message they want to send to stakeholders. It could be that Starbucks' CSR reports, at about twenty pages each, are far shorter than the other public company reports because, while their stakeholders admire their efforts to create a positive impact, their stakeholders also do not want to know that part of the premium prices they pay is because Starbucks' CSR team is trying to save the world.

Viewing CSR strategies as marketing tactics also has implications regarding their financial return on investment. One study found that strategies that involve products, the environment, corporate governance and employees are associated with higher stock prices for companies while community-based strategies such as charitable giving have no affect (Wang et al.). This finding further supports the benefits of internal, compared to external, CSR strategies.

Further research should look more closely at effects that marketing ideology has on CSR strategies and reporting. Due to the inconclusive result regarding the connection between effective CSR strategies and the financial performance of companies, future research should also 
find a method to overcome the barriers faced by this researcher and determine if investing in better CSR strategies is financially justified.

Additionally, while the researcher believed that the research used to create and backup the assessment tool used in this study was sufficient enough for the scope of this project, there is much additional research that should be done to further the understanding of what makes CSR strategies effective.

\section{Works Cited}

2-Layer GORE-TEX® Shell Fabric - Patagonia.

http://www.patagonia.com/2-layer-gore-tex.html. Accessed 17 Jan. 2018.

3m-2014-Sustainability-Report.Pdf.

http://multimedia.3m.com/mws/media/1029600O/3m-2014-sustainability-report.pdf.

Accessed 13 Feb. 2018.

3m-2015-Sustainability-Report.Pdf.

http://multimedia.3m.com/mws/media/10641700/3m-2015-sustainability-report.pdf.

Accessed 13 Feb. 2018.

3ms-2012-Global-Sustainability-Report.Pdf.

http://multimedia.3m.com/mws/media/10296280/3ms-2012-global-sustainability-repor t.pdf. Accessed 13 Feb. 2018. 
3ms-2013-Global-Sustainability-Report.Pdf.

http://multimedia.3m.com/mws/media/1029629O/3ms-2013-global-sustainability-repor t.pdf. Accessed 13 Feb. 2018.

12-088.Pdf. http://www.hbs.edu/faculty/Publication\%20Files/12-088.pdf. Accessed 21 Jan. 2018.

---. http://www.hbs.edu/faculty/Publication\%20Files/12-088.pdf. Accessed 13 Feb. 2018. $19 c 68 e a 6 c 48 a 473 d 865 c 7327 c 08 d 817 f . P d f$.

https://globalassets.starbucks.com/assets/19c68ea6c48a473d865c7327c08d817f.pdf. Accessed 13 Feb. 2018.

100\% for the Planet. http://www.patagonia.com/100-percent-for-the-planet.html. Accessed 17 Jan. 2018.

100\% Recycled Down - Patagonia. http://www.patagonia.com/recycled-down.html. Accessed 17 Jan. 2018.

581d72979ef0486682a5190eca573fef.Pdf. https://globalassets.starbucks.com/assets/581d72979ef0486682a5190eca573fef.pdf. Accessed 13 Feb. 2018.

“2011 SEAR Report | Ben \& Jerry’s.” Http://Www.Benjerry.Com, http://www.benjerry.com/about-us/sear-reports/2011-sear-report. Accessed 18 Jan. 2018.

2011_SevGen_Corporate-Consciousness.Pdf. https://www.seventhgeneration.com/sites/default/files/assets/pdf/2011_SevGen_Corpor ate-Consciousness.pdf. Accessed 20 Jan. 2018. 
2012_sevgen_corporate-Consciousness-Report.Pdf.

https://www.seventhgeneration.com/sites/default/files/2012_sevgen_corporate-consciou sness-report.pdf. Accessed 20 Jan. 2018.

https://www.seventhgeneration.com/sites/default/files/2012_sevgen_corporate-consciou sness-report.pdf. Accessed 20 Jan. 2018.

“2013 SEAR Report | Ben \& Jerry's.” Http://Www.Benjerry.Com, http://www.benjerry.com/about-us/sear-reports/2013-sear-report. Accessed 17 Jan. 2018.

---. Http://Www.Benjerry.Com, http://www.benjerry.com/about-us/sear-reports/2013-sear-report. Accessed 17 Jan. 2018.

2013_sev-Gen_corporate-Consciousness-Report.Pdf. https://www.seventhgeneration.com/sites/default/files/2013_sev-gen_corporate-conscio usness-report.pdf. Accessed 20 Jan. 2018.

“2014 SEAR Report | Ben \& Jerry’s.” Http://Www.Benjerry.Com, http://www.benjerry.com/about-us/sear-reports/2014-sear-report. Accessed 17 Jan. 2018.

2014-Global-Responsibility-Report.Pdf.

http://cdn.corporate.walmart.com/db/e1/b551a9db42fd99ea24141f76065f/2014-global-r esponsibility-report.pdf. Accessed 13 Feb. 2018. 
“2015 SEAR Report | Ben \& Jerry's.” Http://Www.Benjerry.Com, http://www.benjerry.com/about-us/sear-reports/2015-sear-report. Accessed 17 Jan. 2018.

2015-Global-Responsibility-Report.Pdf.

https://cdn.corporate.walmart.com/f2/b0/5b8e63024998a74b5514e078a4fe/2015-global -responsibility-report.pdf. Accessed 13 Feb. 2018.

2015_seventh_generation_corporate-Consciousness-Report.Pdf. https://www.seventhgeneration.com/sites/default/files/2015_seventh_generation_corpor ate-consciousness-report.pdf. Accessed 20 Jan. 2018.

2015_seventh_generation_corporate_responsibility_report.Pdf.

https://www.seventhgeneration.com/sites/default/files/2015_seventh_generation_corpor ate_responsibility_report.pdf. Accessed 20 Jan. 2018.

https://www.seventhgeneration.com/sites/default/files/2015_seventh_generation_corpor ate_responsibility_report.pdf. Accessed 20 Jan. 2018.

“2016 SEAR Report | Ben \& Jerry’s.” Http://Www.Benjerry.Com, http://www.benjerry.com/about-us/sear-reports/2016-sear-report. Accessed 17 Jan. 2018.

---. Http://Www.Benjerry.Com, http://www.benjerry.com/about-us/sear-reports/2016-sear-report. Accessed 17 Jan. 2018. 
2016-3m-Sustainability-Report.Pdf.

http://multimedia.3m.com/mws/media/1214315O/2016-3m-sustainability-report.pdf. Accessed 13 Feb. 2018.

2016-Global-Responsibility-Report.Pdf.

https://cdn.corporate.walmart.com/9c/73/3f9abcef444397f2c771e081e095/2016-globalresponsibility-report.pdf. Accessed 13 Feb. 2018.

2016-Impact-Report.Pdf.

https://www.newseasonsmarket.com/wp-content/uploads/2017/04/2016-Impact-Report. pdf. Accessed 19 Jan. 2018.

2017achhc-Annualreport-Final-Web.Pdf.

https://www.allcarehealth.com/media/1696/2017achhc-annualreport-final-web.pdf. Accessed 19 Jan. 2018.

2017-Sustainability-Report.Pdf.

http://multimedia.3m.com/mws/media/1393020O/2017-sustainability-report.pdf. Accessed 13 Feb. 2018.

9265e80751db48398b88bdf09821cc56.Pdf.

https://globalassets.starbucks.com/assets/9265e80751db48398b88bdf09821cc56.pdf. Accessed 13 Feb. 2018.

About AllCare Health | AllCare Health. https://www.allcarehealth.com/about-us. Accessed 22 Jan. 2018.

About Nike - The Official Corporate Website for NIKE, Inc. and Its Affiliate Brands. https://about.nike.com/. Accessed 22 Jan. 2018. 
Ai Jean, Wong, and Dr. Rashad Yazdanifard. The Review of Shared Value in Contemporary CSR Run by Two Successful Companies to Sustain the Business in Recent Years. Vol. 2, Oct. 2015, pp. 1122-29.

Arena, M., et al. "What Drives the Evolution of Corporate Social Responsibility Strategies? An Institutional Logics Perspective." Journal of Cleaner Production, vol. 171, Jan. 2018, pp. 345-55. CrossRef, doi:10.1016/j.jclepro.2017.09.245.

Bamboo_rayon.Pdf.

http://www.patagonia.com/static/on/demandware.static/-/Library-Sites-PatagoniaShared /default/dw0de5a5be/PDF-US/bamboo_rayon.pdf. Accessed 17 Jan. 2018.

“Ben \& Jerry’s and Greyston Bakery: Great Baked Goods with a Greater-Good Mission." Http://Www.Benjerry.Com, http://www.benjerry.com/greyston. Accessed 17 Jan. 2018.

“Ben \& Jerry’s Fairtrade Ingredients Share The Love.” Http://Www.Benjerry.Com, http://www.benjerry.com/values/issues-we-care-about/fairtrade. Accessed 17 Jan. 2018. Biodegradable_compostable.Pdf.

http://www.patagonia.com/static/on/demandware.static/-/Library-Sites-PatagoniaShared /default/dw94f0d2fb/PDF-US/biodegradable_compostable.pdf. Accessed 17 Jan. 2018. Björkman, Hanna, and Emelie Wong. The Role of Social Auditors: A Categorization of the Unknown. 2013.

Blog | The City of Portland, Oregon.

https://www.portlandoregon.gov/sustainabilityatwork/62148. Accessed 19 Jan. 2018.

Bluesign ${ }^{\circledR}$ Approved Fabrics - Patagonia. http://www.patagonia.com/bluesign-standard.html. Accessed 17 Jan. 2018. 
---. http://www.patagonia.com/bluesign-standard.html. Accessed 17 Jan. 2018.

Brand | $3 M$ United States.

https://www.3m.com/3M/en_US/company-us/3m-science-applied-to-life/. Accessed 22 Jan. 2018.

Burros, Marian. “In Oregon, Thinking Local.” The New York Times, 4 Jan. 2006. NYTimes.com, https:/www.nytimes.com/2006/01/04/dining/in-oregon-thinking-local.html.

Business Collection - Document - Green Business: Reducing Carbon Footprint Cuts Costs and Provides Opportunities.

http://go.galegroup.com/ps/i.do?p=ITBC\&sw=w\&u=s1 185784\&v=2.1\&it=r\&id=GAL E\%7CA266941322\&asid=7b92babe63fb1057a39efb4f911e9c9b. Accessed 13 Feb. 2018.

“Cage Free Eggs | Ben \& Jerry’s.” Http://Www.Benjerry.Com, http://www.benjerry.com/values/how-we-do-business/cage-free-eggs. Accessed 17 Jan. 2018.

“Caring Dairy Standards.” Http://Www.Benjerry.Com, http://www.benjerry.com/whats-new/2016/caring-dairy-standards. Accessed 17 Jan. 2018.

Carr, Austin, et al. "Death To Core Competency: Lessons From Nike, Apple, Netflix.” Fast Company, 14 Feb. 2013, https://www.fastcompany.com/3005850/core-competency-dead-lessons-nike-apple-netf lix. 
Carrol, Archie, and Ann Buchholtz. "The Stakeholder Approach to Business, Society, and Ethics." Business and Society: Ethics, Sustainability, and Stakeholder Management, Cengage Learning, p. 67.

Case_newseasons.Pdf.

https://www.epa.gov/sites/production/files/2015-08/documents/case_newseasons.pdf. Accessed 19 Jan. 2018.

Clean Color: Natural \& Plant-Based Dyes - Patagonia. http://www.patagonia.com/clean-color.html. Accessed 17 Jan. 2018.

“Company Information.” Starbucks Coffee Company, https://www.starbucks.com/about-us/company-information. Accessed 22 Jan. 2018. “Comparing Financial Ratios Between Industries.” THE RESOURCEFUL CEO ${ }^{T M}, 21$ Aug. 2013,

http://theresourcefulceo.com/2013/08/comparing-financial-ratios-between-industries/. corkforest. "New Seasons Partnership." Cork Forest Conservation Alliance, 16 June 2010, http://www.corkforest.org/new-seasons-partnership/. Corporate Responsibility: Working With Factories - Patagonia.

http://www.patagonia.com/working-with-factories.html. Accessed 17 Jan. 2018. “Corporate Social Responsibility Feature: Warby Parker.” Momentum Telecom, 15 Apr. 2013, https://momentumtelecom.com/social-feature-warby-parker/. CSR-2015_Full-Report.Pdf.

http://csrreportbuilder.intel.com/PDFfiles/CSR-2015_Full-Report.pdf. Accessed 13 Feb. 2018. 
CSR-2016_Full-Report.Pdf.

http://csrreportbuilder.intel.com/PDFfiles/CSR-2016_Full-Report.pdf. Accessed 13

Feb. 2018.

Csrframework.Pdf.

http://siteresources.worldbank.org/EXTDEVCOMSUSDEVT/Resources/csrframework. pdf. Accessed 13 Feb. 2018.

Delmas, Magali A., and Vanessa Cuerel Burbano. "The Drivers of Greenwashing." California Management Review, vol. 54, no. 1, 2011, pp. 64-87.

“Do You Know This Term?” BusinessDictionary.Com, http://www.businessdictionary.com/definition/core-competencies.html. Accessed 7 Feb. 2018.

Ea2441eb7cf647bb8ce8bb40f75e267e.Pdf.

https://globalassets.starbucks.com/assets/ea2441eb7cf647bb8ce8bb40f75e267e.pdf. Accessed 13 Feb. 2018.

Ee8121c1a6554399b554d126228d52ed.Pdf.

https://globalassets.starbucks.com/assets/ee8121c1a6554399b554d126228d52ed.pdf. Accessed 13 Feb. 2018.

Environmental Grants \& Funding - Patagonia.

http://www.patagonia.com/environmental-grants.html. Accessed 17 Jan. 2018.

---. http://www.patagonia.com/environmental-grants.html. Accessed 17 Jan. 2018. 
Environmental Grants \& Support - Patagonia.

http://www.patagonia.com/environmental-grants-and-support.html. Accessed 17 Jan. 2018.

Epstein, Mark, and Kristi Yuthas. Measuring and Improving Social Impacts.

Berrett-Koehler Publishers, Inc., 2014.

Explore Portland Oregon » New Seasons Market.

http://www.pdxfamilyadventures.com/2008/01/05/new-seasons-market. Accessed 19 Jan. 2018.

FLASH REPORT: 81\% of S\&P 500 Companies Published Sustainability Reports in 2015. https://www.ga-institute.com/press-releases/article/flash-report-eighty-one-percent-81-o f-the-sp-500-index-companies-published-corporate-sustainabi.html. Accessed 7 Feb. 2018.

Fluorochemicals_030515.Pdf.

http://www.patagonia.com/static/on/demandware.static/-/Library-Sites-PatagoniaShared /default/dw730db104/PDF-US/fluorochemicals_030515.pdf. Accessed 17 Jan. 2018.

García-Jiménez, J. V., et al. "The Impact of Congruence between the CSR Activity and the Company's Core Business on Consumer Response to CSR." Spanish Journal of Marketing - ESIC, vol. 21, July 2017, pp. 26-38. ScienceDirect, doi:10.1016/j.sjme.2017.01.001.

Green_and_business.Pdf. http://www.patagonia.com/static/on/demandware.static/-/Library-Sites-PatagoniaShared /default/dw89fc0023/PDF-US/green_and_business.pdf. Accessed 17 Jan. 2018. 
H2No ${ }^{\circledR}$ Performance Standard - Patagonia. http://www.patagonia.com/h2no.html.

Accessed 17 Jan. 2018.

Hemp Fabric - Organically Grown Hemp - Patagonia.

http://www.patagonia.com/hemp.html. Accessed 17 Jan. 2018.

Holguín-Veras, Jose, et al. MATERIAL CONVERGENCE: AN IMPORTANT AND

UNDERSTUDIED DISASTER PHENOMENON. Rensselaer Polytechnic Institute, http://transp.rpi.edu/ HUM-LOG/Doc/Vault/matcon.pdf. Accessed 7 Feb. 2018.

"How to Fix Corporate Social Responsibility." World Economic Forum,

https://www.weforum.org/agenda/2014/11/how-to-fix-corporate-social-responsibility/.

Accessed 13 Feb. 2018.

Intel 2012 CSR Report.Pdf.

http://csrreportbuilder.intel.com/PDFfiles/archived_reports/Intel\%202012\%20CSR\%20

Report.pdf. Accessed 13 Feb. 2018.

Intel 2013 CSR Report.Pdf.

http://csrreportbuilder.intel.com/PDFfiles/archived_reports/Intel\%202013\%20CSR\%20

Report.pdf. Accessed 13 Feb. 2018.

Intel 2014 CSR Report.Pdf.

http://csrreportbuilder.intel.com/PDFfiles/archived_reports/Intel\%202014\%20CSR\%20

Report.pdf. Accessed 13 Feb. 2018.

ISO 26000 Social Responsibility. https://www.iso.org/iso-26000-social-responsibility.html.

Accessed 13 Feb. 2018. 
“Join the Climate Movement!" Http://Www.Benjerry.Com, http://www.benjerry.com/values/issues-we-care-about/climate-justice. Accessed 17 Jan. 2018.

Keys, Tracey, et al. Making the Most of Corporate Social Responsibility $\mid$ McKinsey \& Company. https://www.mckinsey.com/global-themes/leadership/making-the-most-of-corporate-so cial-responsibility. Accessed 22 Jan. 2018.

---. Making the Most of Corporate Social Responsibility | McKinsey \& Company. https://www.mckinsey.com/global-themes/leadership/making-the-most-of-corporate-so cial-responsibility. Accessed 8 Feb. 2018.

---. Making the Most of Corporate Social Responsibility | McKinsey \& Company. https://www.mckinsey.com/global-themes/leadership/making-the-most-of-corporate-so cial-responsibility. Accessed 13 Feb. 2018.

Latter, Tony. "How Corporate Social Responsibility Drives Business Performance." HRPS $B \log$, https://blog.hrps.org/blogpost/How-Corporate-Social-Responsibility-Drives-Business-P erformance. Accessed 13 Feb. 2018.

Laughland, Pam. "Stakeholder Relations Sustain Positive Financial Performance." NBS, https://nbs.net/p/stakeholder-relations-sustain-positive-financial-perfor-54a3c28d-41234339-9500-944e3d59a2bf. Accessed 13 Feb. 2018.

Locating the 'Environment' Within Corporate Social Responsibility: Continuing Problems of Legal Definition and Representation : Perspectives on Corporate Social 
Responsibility. 30 Sept. 2008,

https://www.elgaronline.com/view/9781847205612.00012.xml.

Made_in_China_EN.Pdf.

http://www.patagonia.com/static/on/demandware.static/-Library-Sites-PatagoniaShared /default/dw29ab8345/PDF-US/Made_in_China_EN.pdf. Accessed 17 Jan. 2018.

Measure What Matters Most | B Impact Assessment. https://bimpactassessment.net/.

Accessed 10 Feb. 2018.

Mishra, Saurabh, and Sachin B. Modi. "Corporate Social Responsibility and Shareholder Wealth: The Role of Marketing Capability.” Journal of Marketing, vol. 80, no. 1, Jan. 2016, pp. 26-46. CrossRef, doi:10.1509/jm.15.0013.

Neoprene_from_limestone.Pdf.

http://www.patagonia.com/static/on/demandware.static/-Library-Sites-PatagoniaShared /default/dw35ebacd1/PDF-US/neoprene_from_limestone.pdf. Accessed 17 Jan. 2018.

"New Seasons Market Buzzes with Rooftop Beehives.” New Hope Network, 24 Apr. 2013, http://www.newhope.com/news-amp-analysis/new-seasons-market-buzzes-rooftop-bee hives.

New Seasons Market Earns EPA Platinum Certification | Progressive Grocer. https://progressivegrocer.com/new-seasons-market-earns-epa-platinum-certification. Accessed 19 Jan. 2018.

"New Seasons Market Recognized as a Zero Waste Company." PDX Food Press, 25 Apr. 2013, https://pdxfoodpress.com/new-seasons-market-recognized-as-a-zero-waste-company/. 
"New Seasons Market Wins First Green Business of the Year Award.” Clark County

Washington, 25 Mar. 2016,

https:/www.clark.wa.gov/public-health/new-seasons-market-wins-first-green-businessyear-award.

O’Donnell, Joe. "How Patagonia Are Revolutionising CSR \& Sustainability.” CSR Central, 4 Mar. 2015, http://csrcentral.com/patagonia-the-clothing-company-with-a-revolutionary-approach-to -csr-sustainability/.

Our Business. https://corporate.walmart.com/our-story/our-business. Accessed 22 Jan. 2018.

Our Business and Climate Change - Patagonia.

http://www.patagonia.com/climate-change.html. Accessed 17 Jan. 2018.

“Our DWR Problem [Updated].” The Cleanest Line, 8 Sept. 2015, https://www.patagonia.com/blog/2015/09/our-dwr-problem-updated/.

Our History | B Corporation.

http://www.bcorporation.net/what-are-B-corps/the-non-profit-behind-B-corps/our-histo ry. Accessed 10 Feb. 2018.

Paper_Procurement_Policy_EN_051116.Pdf.

http://www.patagonia.com/static/on/demandware.static/-/Library-Sites-PatagoniaShared /default/dw62a9a500/PDF-US/Paper_Procurement_Policy_EN_051116.pdf. Accessed 17 Jan. 2018.

Patagonia ${ }^{\circledR}$ Denim - 100\% Organic Cotton Denim Fabric.

http://www.patagonia.com/denim.html. Accessed 17 Jan. 2018. 
Patagonia, Inc. | B Corporation. http://www.bcorporation.net/community/patagonia-inc.

Accessed 17 Jan. 2018.

Patagonia Outdoor Clothing \& Gear. http://www.patagonia.com/home/. Accessed 22 Jan. 2018.

Patagonia_Benchmarks_12-27-12_English.Pdf.

http://www.patagonia.com/static/on/demandware.static/-/Library-Sites-PatagoniaShared /default/dw5dff9c3e/PDF-US/Patagonia_Benchmarks_12-27-12_English.pdf. Accessed 17 Jan. 2018.

http://www.patagonia.com/static/on/demandware.static/-/Library-Sites-PatagoniaShared /default/dw5dff9c3e/PDF-US/Patagonia_Benchmarks_12-27-12_English.pdf. Accessed 17 Jan. 2018.

Patagonia_COC_English_02_13.Pdf.

http://www.patagonia.com/static/on/demandware.static/-/Library-Sites-PatagoniaShared /default/dw63489f7b/PDF-US/Patagonia_COC_English_02_13.pdf. Accessed 17 Jan. 2018.

Patagonia-Finished-Goods-Supplier-List-5Apr2017.Pdf.

http://www.patagonia.com/static/on/demandware.static/-/Library-Sites-PatagoniaShared /default/dw291a1382/PDF-US/Patagonia-Finished-Goods-Supplier-List-5Apr2017.pdf. Accessed 17 Jan. 2018.

Patagonia-Global-Recycling-Strategy-and-Upcycling-Policy.Pdf.

http://www.patagonia.com/static/on/demandware.static/-/Library-Sites-PatagoniaShared 
/default/dw2ca0a0c1/PDF-US/Patagonia-Global-Recycling-Strategy-and-Upcycling-Po licy.pdf. Accessed 17 Jan. 2018.

Patagonia.Pdf. https://danielsethics.mgt.unm.edu/pdf/patagonia.pdf. Accessed 17 Jan. 2018. Patagonia's Tools for Grassroots Activist Conference.

http://www.patagonia.com/tools-conference.html. Accessed 17 Jan. 2018.

Pla_and_corn.Pdf.

http://www.patagonia.com/static/on/demandware.static/-/Library-Sites-PatagoniaShared /default/dwc2a9fddb/PDF-US/pla_and_corn.pdf. Accessed 17 Jan. 2018.

Polygiene ${ }^{\circledR}$ Odor Control Fabric - Patagonia. http://www.patagonia.com/polygiene.html. Accessed 17 Jan. 2018.

"Poverty, Inc." Poverty, Inc., https://www.povertyinc.org/. Accessed 7 Feb. 2018.

Press Releases.

https://www.ga-institute.com/press-releases/article/flash-report-eighty-one-percent-81-o f-t. Accessed 7 Feb. 2018.

PrimaLoft ${ }^{\circledR}$ Insulation - Patagonia. http://www.patagonia.com/primaloft.html. Accessed 17 Jan. 2018.

Principles of Fair Labor and Responsible Sourcing and Production | Fair Labor Association. http://www.fairlabor.org/our-work/principles. Accessed 17 Jan. 2018. Pvc_printing_inks_and_phtalates.Pdf.

http://www.patagonia.com/static/on/demandware.static/-Library-Sites-PatagoniaShared /default/dw5c459373/PDF-US/pvc_printing_inks_and_phtalates.pdf. Accessed 17 Jan. 2018. 
Reclaimed Cotton Fabric - Patagonia. http://www.patagonia.com/reclaimed-cotton.html.

Accessed 17 Jan. 2018.

Recycled Nylon Fabric - Patagonia. http://www.patagonia.com/recycled-nylon.html.

Accessed 17 Jan. 2018.

Recycled Wool Fabric - Patagonia. http://www.patagonia.com/recycled-wool.html.

Accessed 17 Jan. 2018.

“Seventh Generation.” Seventh Generation, https:/www.seventhgeneration.com/. Accessed 22 Jan. 2018.

Seventh_generation_corporate_consciousness_report_2016.Pdf.

https://www.seventhgeneration.com/sites/default/files/seventh_generation_corporate_c onsciousness_report_2016.pdf. Accessed 19 Jan. 2018.

“Social Mission Possible: Ben \& Jerry’s Chief Euphoria Officer on the Urgency of Climate Action." Http://Www.Benjerry.Com, http://www.benjerry.com/values/issues-we-care-about/climate-justice/life-cycle-analysi s. Accessed 17 Jan. 2018.

---. Http://Www.Benjerry.Com, http://www.benjerry.com/values/issues-we-care-about/climate-justice/life-cycle-analysi s. Accessed 17 Jan. 2018.

Something New under the Sun | The Economist.

http://www.economist.com/node/9928154\#print?story_id=9928154. Accessed 7 Feb. 2018. 
“Support GMO Labeling | Ben \& Jerry’s." Http://Www.Benjerry.Com, http://www.benjerry.com/GMO. Accessed 17 Jan. 2018.

The Forum for Sustainable and Responsible Investment. https://www.ussif.org/sribasics. Accessed 10 Feb. 2018.

The Sustainability Imperative.

http://www.nielsen.com/us/en/insights/reports/2015/the-sustainability-imperative. Accessed 7 Feb. 2018.

Traceable Down Insulation - Patagonia. http://www.patagonia.com/traceable-down.html. Accessed 17 Jan. 2018.

Triangulating Environmental Performance: What Do Corporate Social Responsibility Ratings Really Capture? http://amp.aom.org/content/27/3/255.abstract. Accessed 13 Feb. 2018.

Updated-2013-Global-Responsibility-Report_130113953638624649.Pdf.

http://cdn.corporate.walmart.com/39/97/81c4b26546b3913979b260ea0a74/updated-201 3-global-responsibility-report_130113953638624649.pdf. Accessed 13 Feb. 2018.

http://cdn.corporate.walmart.com/39/97/81c4b26546b3913979b260ea0a74/updated-201

3-global-responsibility-report_130113953638624649.pdf. Accessed 13 Feb. 2018.

Wang, Heli, et al. "Corporate Social Responsibility: An Overview and New Research Directions: Thematic Issue on Corporate Social Responsibility.” Academy of Management Journal, vol. 59, no. 2, Apr. 2016, pp. 534-44. CrossRef, doi:10.5465/amj.2016.5001. 
Welcome to FishWise.

https://www.fishwise.org/2016/02/16/fishwise-partners-with-new-seasons-market/. Accessed 19 Jan. 2018.

What We Know and Don't Know About Corporate Social Responsibility: A Review and Research Agenda - Herman Aguinis, Ante Glavas, 2012. http://journals.sagepub.com/doi/abs/10.1177/0149206311436079. Accessed 13 Feb. 2018.

White, Gillian B. "All Your Clothes Are Made With Exploited Labor.” The Atlantic, June 2015. The Atlantic, https://www.theatlantic.com/business/archive/2015/06/patagonia-labor-clothing-factory -exploitation/394658/.

Why B Corps Matter |B Corporation. http://www.bcorporation.net/what-are-B-corps/why-B-corps-matter. Accessed 9 Feb. 2018.

Wmt-2017-Grr-Report-Final.Pdf. https://cdn.corporate.walmart.com/6c/d4/d2a7f2c644c9a696063b083ca932/wmt-2017-g rr-report-final.pdf. Accessed 13 Feb. 2018.

Yulex ${ }^{\circledR}$ Guayule Rubber - Patagonia. http://www.patagonia.com/yulex.html. Accessed 17 Jan. 2018.

---. http://www.patagonia.com/yulex.html. Accessed 17 Jan. 2018. 


\section{Appendix}

\section{Appendix A}

\section{Core Competencies}

Core competencies were derived from companies' mission statements and their primary product offerings.

3M: "Science is at the heart of everything we do." Their core competency is manufacturing new inventions.

Starbucks: "Our mission to inspire and nurture the human spirit - one person, one cup, and one neighborhood at a time." Their core competency is creating food and beverage experiences that support the communities of people who support and consume them. Because their mission specifically involves helping communities, volunteering scored a 2 in this category.

Walmart Core Strategy: "Everyday low prices on a broad assortment - anytime, anywhere." Their core competency is competing on product variety and price in the retail industry.

Nike Core Strategy: "Bring inspiration and innovation to every athlete in the world." Their core 
competency is creating products that enable athleticism. Since environmental and social sustainability are not a part of their core competencies, their social and environmental strategies only scored a 1 or a 2 on the "Aligns with Core Competencies" factor if they were specifically related to product production. Strategies involving employee diversity were given a 1 for the "Aligns with Core Competencies" factor because Nike strives to promote athleticism among all demographics and they need a diverse workforce to fully understand and meet the needs of diverse communities.

Intel Core Strategy: "Intel invents at the boundaries of technology to make amazing experiences possible for business and society and for every person on earth.” Their core competency is inventing technology that accelerates the computing industry.

Patagonia Core Strategy: "Build the best product, cause no unnecessary harm, use business to inspire and implement solutions to the environmental crisis." Their core competency is creating environmentally sustainable outdoor products.

Seventh Generation Core Strategy: 'Creating powerful plant-based solutions for your home and family." Their core competency is creating less toxic, environmentally-friendly home products.

Ben and Jerry's Core Strategy: Their strategy has three parts: "Make fantastic ice cream." "Manage our company for sustainable financial growth." "Innovate ways to make the world a 
better place." Their core competency is creating socially and environmentally-friendly ice cream.

New Season's Core Strategy: "New Seasons Market brings delicious, healthy food from local farmers, producers, ranchers \& fishermen to our communities.” Their core competency is sourcing and selling healthy, locally-produced food.

AllCare Health Core Strategy: "We are a physician-led organization leading the way to better healthcare for Oregon and its people, with a range of plans designed to meet the state's diverse communities and their health needs." Their core competency is providing healthcare services.

\section{Appendix B}

Applying the Results: How to Maximize the Impact of Your CSR Strategies

This appendix shows how this study can be used to inform CSR strategy planning and development.

With the CSR budgets for companies ranging from a fraction of a percent to ten percent of revenue, it's important for managers to evaluate how they can create the biggest impact with their limited funds. This study revealed that internal strategies - those that directly change a company's operations make a significantly bigger impact than external strategies.

Here's how to create effective internal strategies based on the assessment tool used in the study: 


\section{1) Does the strategy align with your company's core competencies? The best CSR}

strategies capitalize on what your company is already great at. Not only does this tend to make your strategies more effective, consumers are more likely to believe that companies genuinely care about the causes they are supporting if the strategies directly relate to a core aspect of the business. For example, Patagonia's core competency is creating environmentally-friendly clothing so many of their strategies revolved around using more sustainable materials and manufacturing processes.

2) Your strategies must have measurable performance. This includes both financial and social measurability, though strategies do not need to have both. Measurability is key because it's the only way to know if your strategies are worth the investment or if you need to replace them with something more effective. In this study, manufacturing-based companies such as Nike and 3M did especially well on this factor because many of their strategies involved reducing the percentage of waste, energy, emissions and other outputs that are harmful to the environment while increasing their percentage of sustainable inputs such as renewable energy and environmentally and socially-friendly materials

3) Strategies should demonstrate a long-term commitment to a cause. It's impossible to fix a major social or environmental issue with short-term strategies. To truly make an impact, strategies should be designed to be maintained and improved upon for the long-term. One way of doing this is creating social and/or sustainability standards that 
periodically updated to force the company and/or its suppliers to raise the bar. Every few years, Ben and Jerry's increases the standards for their Caring Dairy certification so that their dairy suppliers have to become more socially and environmentally responsible.

4) Your strategies should benefit your primary stakeholders. Primary stakeholders are the entities, including the natural environment, that are directly affected by your business. Creating strategies that benefit them is key because they're the ones who you're most likely to receive bad publicity and lose sales from if you harm. It is also easier to create strategies that benefit them because you don't have to leave your facilities. Common examples of strategies that embody this factor include special benefits for employees and contract workers, reducing the impact of manufacturing plants on surrounding communities, and providing customers access to socially and environmentally responsible goods at accessible prices. While internal strategies overall scored higher in this study, there are some external strategies that can benefit primary stakeholders without a large investment. For example. 3M has beehives and nature preserves surrounding some of its facilities to mitigate its impact on the surrounding environment.

5) The most effective strategies are innovative. The business world, natural environment and social needs are changing more rapidly than ever before. To make an impact, companies must adapt their strategies to these changes and be constantly improving. Several of the companies in this scored high on this factor by constantly working to develop more socially and environmentally responsible materials and products. In many 
cases such as Nike's Colordry technology that dies fabric without water and Seventh Generation's cleaning supplies that have eliminated toxins found in the vast majority of products on the market, the companies created solutions that had never before existed. It's that kind of innovation businesses need to strive for.

By using these factors as a guiding framework, it simplifies the process it takes for businesses to learn which of their existing strategies are truly making a positive impact and how to create new ones that do.

\section{Appendix C}

\section{Complete list of Public Company Strategies and Scores}

This is a complete list of strategies whose sole purpose is to show readers how this type of scoring can be done. Nothing from this point forward needs to be read to understand the thesis. Many of the strategies are written in the researchers shorthand terms to substantially reduce the time it took to document the strategies.

$3 m$

\begin{tabular}{|c|c|c|c|}
\hline Internal Strategies & Scores & External Strategies & Scores \\
\hline $\begin{array}{l}17 \text { - Inclusive parental leave policy including } \\
\text { men and adoptive parents }\end{array}$ & 7 & $\begin{array}{l}17 \text { - Partnered with Smithsonian to open an } \\
\text { African American History Museum }\end{array}$ & 4 \\
\hline $\begin{array}{l}17 \text { - fast-tracked production of water filters } \\
\text { for Flint MI }\end{array}$ & 5 & On-going - honeybee colony at headquarters & 8 \\
\hline 17 - Solar roof tiles & 9 & 17 - donate water filters & 4 \\
\hline $\begin{array}{l}17 \text { - fingerprint scanner to give people in } \\
\text { India legal identities - worked with the } \\
\text { country's government }\end{array}$ & 9 & $\begin{array}{l}\text { on-going - legal affairs team does pro bono } \\
\text { work }\end{array}$ & 3 \\
\hline $\begin{array}{l}17 \text { - cool roof shingles to reduce urban heat } \\
\text { island effect }\end{array}$ & 10 & $\begin{array}{l}17 \text { - over purchases over } \$ 20,000 \text { in Global } \\
\text { Giving gift cards to pass out at conferences and }\end{array}$ & 2 \\
\hline
\end{tabular}




\begin{tabular}{|c|c|c|c|}
\hline & & other events & \\
\hline $\begin{array}{l}17 \text { - disposal respirator stockpile maintenance } \\
\text { program (personal healthcare issue) }\end{array}$ & 10 & On-going - WorldSkills partnership & 4 \\
\hline $\begin{array}{l}17 \text { - created an ointment to help incontinence } \\
\text { (skin care issue) }\end{array}$ & 10 & $\begin{array}{l}\text { by } 2025 \text {-provide training to } 5 \text { million people on } \\
\text { worker safety }\end{array}$ & 7 \\
\hline $\begin{array}{l}17 \text { - created daylight redirecting film for } \\
\text { stores like Walgreens to be able to use more } \\
\text { natural light }\end{array}$ & 10 & $\begin{array}{l}\text { on-going - every year invests in over half a } \\
\text { dozen education programs }\end{array}$ & 5 \\
\hline $\begin{array}{l}\text { ongoing - disability and pension plans for } \\
\text { employees }\end{array}$ & 6 & $\begin{array}{l}2016 \text { - donated } \$ 67,300,000 \text { and } 348,000 \\
\text { volunteer hours }\end{array}$ & 4 \\
\hline $\begin{array}{l}\text { By } 2025 \text { - total electricity from renewable } \\
\text { sources - one solar project in India is project } \\
\text { to save } 1.3 \text { million in electricity costs over its } \\
20 \text { year life }\end{array}$ & 8 & $\begin{array}{l}\text { ongoing - partners with several science and } \\
\text { cultural museums around the US }\end{array}$ & 4 \\
\hline $\begin{array}{l}\text { by } 2025 \text { - achieve zero landfill status at } 30 \% \\
\text { of manufacturing plants }\end{array}$ & 8 & $\begin{array}{l}2015 \text { - supports CALSO - a social } \\
\text { entrepreneurship incubator }\end{array}$ & 4 \\
\hline $\begin{array}{l}\text { by } 2025 \text { - reduce global manufacturing waste } \\
\text { by } 10 \%\end{array}$ & 8 & $\begin{array}{l}\text { on-going - partnered with local environmental } \\
\text { group to protect species that live on their } \\
\text { property such as endangered nesting birds }\end{array}$ & 7 \\
\hline by 2025 - reduce global water use by $10 \%$ & 8 & $\begin{array}{l}\text { on-going - involved in many business } \\
\text { associations and nonprofits that focus on helping } \\
\text { businesses become more responsible }\end{array}$ & 5 \\
\hline by 2025 - improve energy efficiency by $30 \%$ & 8 & $\begin{array}{l}\text { on-going - advocating on behalf of a list of } \\
\text { public policy issues that align with their goals }\end{array}$ & 5 \\
\hline by 2025 - reduce emissions by $50 \%$ of 2002 & 8 & $\begin{array}{l}\text { on-going - partnered with the Nature } \\
\text { Conservancy }\end{array}$ & 4 \\
\hline $\begin{array}{l}\text { by } 2025 \text { - help customers reduce emissions } \\
\text { by } 250 \text { million tons }\end{array}$ & 10 & $\begin{array}{l}\text { on-going - other short-term partnerships to fund } \\
\text { nonprofit projects }\end{array}$ & \\
\hline $\begin{array}{l}\text { ongoing - will not outsource to any company } \\
\text { who hires workers under the age of } 16\end{array}$ & 6 & & \\
\hline $\begin{array}{l}17 \text { - estimated } 6 \text { million energy savings by } \\
\text { switching to LED lights }\end{array}$ & 8 & & \\
\hline $\begin{array}{l}\text { on-going - life cycle management } \\
\text { assessments for their products }\end{array}$ & 9 & & \\
\hline $\begin{array}{l}16 \text { - reduced packaging weight for } 7 \text { straight } \\
\text { years - over } 9,000 \text { metric tons saved }\end{array}$ & 9 & & \\
\hline $\begin{array}{l}16 \text { - over } 30 \% \text { of their US suppliers are from } \\
\text { small and/or diversely-owned businesses }\end{array}$ & 8 & & \\
\hline $\begin{array}{l}2010-2015 \text { - reduced hazardous waste by } \\
13 \%\end{array}$ & 8 & & \\
\hline
\end{tabular}




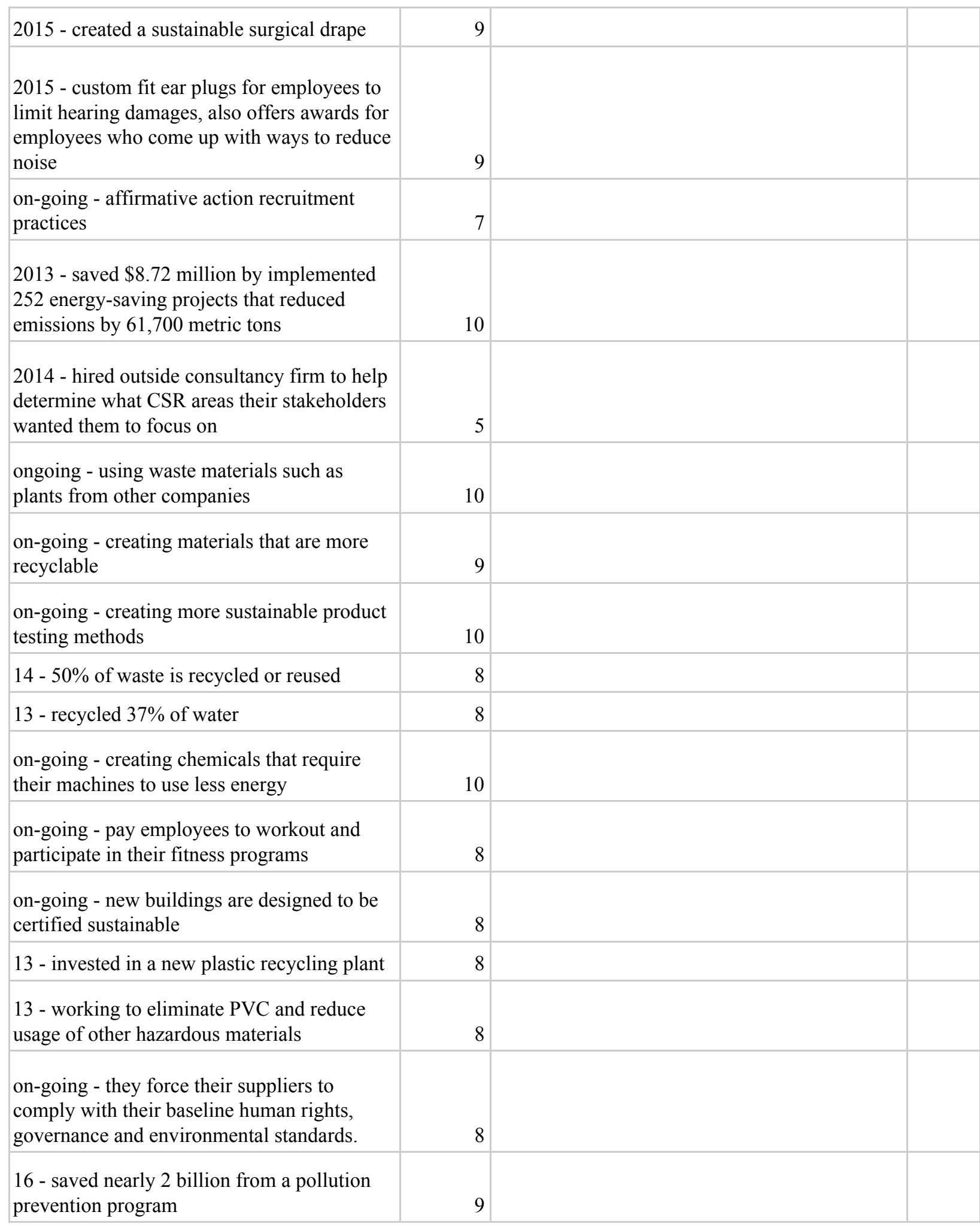

\section{Starbucks}




\begin{tabular}{|c|c|c|c|}
\hline $\begin{array}{l}2016 \text { - reached } 99 \% \text { ethically sourced coffee } \\
\text { beans }\end{array}$ & 8 & $\begin{array}{l}\text { ongoing - discount to customers who bring in a } \\
\text { reusable cup }\end{array}$ & 8 \\
\hline $\begin{array}{l}\text { on-going - partnered with Conservation } \\
\text { International to help their coffee farmers } \\
\text { become more environmentally and } \\
\text { economically sustainable }\end{array}$ & 9 & $\begin{array}{l}2020 \text { - Partner with Feeding America to donate } \\
100 \% \text { of excess food from American retail } \\
\text { stores - expected to yield } 50 \text { million meals } \\
\text { annually }\end{array}$ & 5 \\
\hline $\begin{array}{l}2025 \text { - by this year will donate } 100 \text { million } \\
\text { coffee trees }\end{array}$ & 8 & $\begin{array}{l}2020-100 \% \text { of Starbucks stores globally will } \\
\text { participate in community service }\end{array}$ & 6 \\
\hline $\begin{array}{l}\text { on-going - } 50 \text { million dollar Global Farmer } \\
\text { Fund to finance small coffee farmers and help } \\
\text { them grow their businesses }\end{array}$ & 8 & $\begin{array}{l}\text { on-going - as of } 2016 \text {, partnered with } 63 \text { youth } \\
\text { organizations in } 10 \text { countries }\end{array}$ & 5 \\
\hline on-going - 1,200 LEED certified stores & 6 & $\begin{array}{l}\text { on-going - partnered with an unknown amount } \\
\text { of organization local to their coffee growing } \\
\text { communities }\end{array}$ & 7 \\
\hline $2025-10,000$ greener retail stores & 7 & 2014 - Starbucks Foundation gave 13.1 million & 4 \\
\hline $\begin{array}{l}\text { on-going - } 10 \% \text { post-consumer fiber in hot } \\
\text { cups }\end{array}$ & 8 & ongoing - Coffee and Farmer Equity partnership & 7 \\
\hline $\begin{array}{l}2022 \text { - double the amount of communities } \\
\text { where cups can be recycled }\end{array}$ & 9 & on-going - Ethical Tea Partnership & 7 \\
\hline $\begin{array}{l}2016 \text { - purchased renewable energy for } 100 \% \\
\text { of its stores }\end{array}$ & 6 & $\begin{array}{l}\text { on-going - partnered with Fairtrade Access } \\
\text { Fund }\end{array}$ & 7 \\
\hline $\begin{array}{l}2016 \text { - sustainability course for their } \\
\text { employees }\end{array}$ & 5 & on-going - partnered with Calvert Foundation & 5 \\
\hline 2025 - hire 25,000 vets and spouses & 7 & on-going - partnered with Verde Ventures & 5 \\
\hline 2020 - hire 10,000 refugees & 7 & on-going - BICEP partnership & 5 \\
\hline $\begin{array}{l}\text { on-going - very strong affirmative action } \\
\text { hiring and promotion plans }\end{array}$ & 7 & $\begin{array}{l}2013 \text { - donated over } 500,000 \text { trees to help small } \\
\text { farmers participate in carbon markets }\end{array}$ & 8 \\
\hline on-going - affirmative action supply chain & 8 & on-going - ethos water fund & 4 \\
\hline $\begin{array}{l}2015 \text { - reduced water consumption by } 26 \% \\
\text { compared to } 2008\end{array}$ & 7 & $\begin{array}{l}\text { on-going - BLEND project to help Indonesian } \\
\text { Youth }\end{array}$ & 4 \\
\hline $\begin{array}{l}2015 \text { - reduced store energy consumption by } \\
5 \%\end{array}$ & 7 & on-going - education for children in Guatemala & 4 \\
\hline $\begin{array}{l}2014-47 \% \text { of North American stores have } \\
\text { recycle bins }\end{array}$ & 6 & on-going - Mercy Corps partnership & 4 \\
\hline $2013-8 \%$ fairtrade coffee & 8 & on-going - Coffeeland Food Security Coalition & 7 \\
\hline $2013-1.1 \%$ organic coffee & 8 & $\begin{array}{l}\text { on-going - Project Concern International } \\
\text { Partnership }\end{array}$ & 4 \\
\hline 2013 onward - $100 \%$ ethically sourced tea & 8 & $\begin{array}{l}\text { on-going - US Green Building Council } \\
\text { Partnership }\end{array}$ & 5 \\
\hline
\end{tabular}




\begin{tabular}{|c|c|c|}
\hline $\begin{array}{l}\text { on-going - discontinue working with } \\
\text { merchandise suppliers who don't meet their } \\
\text { ethical requirements }\end{array}$ & 8 & ongoing - Paper Recovery Partnership \\
\hline 2013 - reverse osmosis filter to reduce water & 6 & on-going - RED partnership \\
\hline 2012 - earth sleeve coffee cup sleeve & 9 & \\
\hline $\begin{array}{l}\text { on-going - multiple community stores } \\
\text { designed to serve their neighborhoods }\end{array}$ & 9 & \\
\hline $\begin{array}{l}2015 \text { - 100,000 Opportunities - partnership } \\
\text { with other businesses to hire youth. }\end{array}$ & 7 & \\
\hline on-going - College Achievement Plan & 8 & \\
\hline $\begin{array}{l}2012 \text { - Apprenticeship program for young } \\
\text { employees }\end{array}$ & 8 & \\
\hline $\begin{array}{l}2020 \text { - train } 200,000 \text { coffee farmers through } 8 \\
\text { global Farmer Support Centers that offer } \\
\text { farmers free access to the latest coffee } \\
\text { growing research. }\end{array}$ & 8 & \\
\hline $\begin{array}{l}\text { on-going - Partnered with Root Capital to help } \\
\text { give farmer loans }\end{array}$ & 7 & \\
\hline
\end{tabular}

\begin{tabular}{|c|c|c|c|}
\hline \multicolumn{4}{|c|}{ Walmart } \\
\hline Internal Strategies & Scores & External Strategies & Scores \\
\hline $\begin{array}{l}\text { 2013-2023 - } 250 \text { billion in products that } \\
\text { support American jobs }\end{array}$ & & $\begin{array}{l}2017 \text { - } 6.8 \text { million donated to disaster } \\
\text { relief }\end{array}$ & 2 \\
\hline 2017 - 26\% renewable energy globally & & $\begin{array}{l}2017-2.4 \text { billion }+ \text { meals provided } \\
\text { since } 2014\end{array}$ & 5 \\
\hline $2017-77 \%$ of waste diverted from landfills & & $\begin{array}{l}2017 \text { - } 100 \text { million donated through } \\
\text { Walmart Foundation }\end{array}$ & 4 \\
\hline $\begin{array}{l}2017 \text { - } 76 \text { million acres diverted to sustainable } \\
\text { fertilizer }\end{array}$ & & $\begin{array}{l}\text { on-going - funding other initiatives to } \\
\text { help employers and workers }\end{array}$ & 4 \\
\hline $\begin{array}{l}2017-96 \% \text { reduction in supplier high-priority } \\
\text { chemicals since } 2014\end{array}$ & & $\begin{array}{l}2017-500,000 \text { in grants to support } \\
\text { community cohesion }\end{array}$ & 4 \\
\hline $\begin{array}{l}2017 \text { - } 200 \text { billion worth of goods evaluated } \\
\text { for sustainability }\end{array}$ & & $\begin{array}{l}\text { 2007-2017 - } 10 \text { million donation to } \\
\text { Operation Homefront }\end{array}$ & 4 \\
\hline 2017 - paid time off for hourly employees & & $\begin{array}{l}\text { on-going - Coalition for Veteran owned } \\
\text { business partnership }\end{array}$ & 5 \\
\hline $\begin{array}{l}2017 \text { - } 700 \text { million }+ \text { in bonuses for hourly } \\
\text { employees }\end{array}$ & & $\begin{array}{l}\text { on-going - global women's } \\
\text { empowerment initiative }\end{array}$ & 3 \\
\hline 2017 - short-term disability plan & & $\begin{array}{l}\text { on-going - women in factories training } \\
\text { program }\end{array}$ & 3 \\
\hline on-going - affirmative action program & 7 & 72016 - US Manufacturing Summit & 4 \\
\hline
\end{tabular}


on-going - associate resource groups to help with things like diversity

on-going - lots of other incentives and support for veterans

on-going - women in retail program

2023 - removed 2.5 ocean shipping containers by sourcing locally

2017 - invested 100 million in training employees to exceed beyond retail

ongoing - source from small/medium sized farmers to help them grow

2011-2017 - sourced 21 billion in products from women-owned businesses

2017 - Supplier Alliance - gives qualified suppliers payments earlier so they have increased capital

2017 - new bread package will save 5 million pounds of bread packaging annually

2017 - reduced operations waste produced by $2 \%$

2017 - developed a coconut-based material to absorb gas spills that can later be used as fuel

2017 - 1.7 million for disaster relief for associates

on-going - provide associated with antitrust training

on-going - improve food forecasting to adjust inventory levels and limit waste

2017 - in mexico diverted 303 tons of food waste to create animal feed

2017 - in UK developed ways to turn food waste into fuel and fertilizer

2017 - 760 on-site water treatment plants in Mexico
2014 - 10 million dollar US

7 Manufacturing Innovation Fund

ongoing - Foundation provides training

7 to small farmers

2017 - International Fertilizer

Development Center training for small

7 farmers

72017 - 1 million dollar grant to OAF

62017 - partnership with Technoserve

on-going - support of Consumer Goods

7 Forum

ongoing - build and donate wetlands to

7 cities and nonprofits

on-going - partnered with the National

Fish and Wildlife Foundation to conserve 1.2 million acres of land and counting, also connected 10 million acres of existing wildlife areas, 2

7 million acres by 2025

2017 - 110,00 volunteer hours toward 8 hunger relief

2017 - Foundation donated 12 million to

7 support children hunger relief

2017 - donated 600 million pounds of

8 unsold food

2017 - created a coalition of big businesses to give bottled water to flint

7 school children

2017 - donated 1.5 million to Red Cross

to help them develop technology to

7 better distribute resources in disasters

on-going - donates a considerable

amount to Red Cross for various

9 projects

2017 - 300,000 grant to Cities of

7 Service

2017 - 100 million dollars of

8 community grants

on-going - south africa business spends

$8 \quad 1-2 \%$ after tax profits on the community
4

3

3

1

4 


\begin{tabular}{|c|c|c|c|}
\hline $\begin{array}{l}2017 \text { - South Africa operations harvests } \\
\text { rainwater }\end{array}$ & 7 & $\begin{array}{l}\text { ongoing - associates earn donations to } \\
\text { favorite charities by volunteering at } \\
\text { least } 25 \text { hours - } 1.2 \text { million hours and } 12 \\
\text { million dollars of walmart donations in } \\
2017\end{array}$ & 4 \\
\hline 2017 - cut water used to wash fleet in half & 8 & $\begin{array}{l}\text { on-going - legal team does pro-bono } \\
\text { work }\end{array}$ & 4 \\
\hline $\begin{array}{l}2017 \text { - reclaimed } 86 \% \text { of water used to wash } \\
\text { fleet }\end{array}$ & 8 & $\begin{array}{l}\text { ongoing - creative team creates } \\
\text { community art }\end{array}$ & 4 \\
\hline $\begin{array}{l}2017 \text { - reduced energy/chemicals needs to } \\
\text { wash fleet by } 76 \%\end{array}$ & 8 & $\begin{array}{l}\text { on-going - Argentine stores collect } \\
\text { money for charity }\end{array}$ & 3 \\
\hline $\begin{array}{l}2017 \text { - maintains } 150 \text { wetlands on its } \\
\text { properties in the US }\end{array}$ & 8 & on-going - Indian stores collect blood & 6 \\
\hline $\begin{array}{l}2017 \text { - added high-efficiency parking lot lights } \\
\text { to } 1,190 \text { US locations }\end{array}$ & 7 & $\begin{array}{l}\text { on-going - Japanese stores raise money } \\
\text { for four causes }\end{array}$ & 4 \\
\hline $\begin{array}{l}\text { ongoing - energy management systems in } \\
\text { China and other markets }\end{array}$ & 7 & $\begin{array}{l}\text { on-going - US stores raise money for } \\
\text { Children's Miracle Network }\end{array}$ & 3 \\
\hline $\begin{array}{l}\text { on-going - incentivise store employees to cut } \\
\text { energy - worked in Argentina - stores cut } \\
\text { energy by } 5 \% \text { for several months }\end{array}$ & 7 & $\begin{array}{l}2017 \text { - funding for Aspen Network of } \\
\text { Development Entrepreneurs }\end{array}$ & 3 \\
\hline on-going - phasing HFCs out of refrigeration & 7 & $\begin{array}{l}2017 \text { - donated } 13,000 \text { tons of unsold } \\
\text { products }\end{array}$ & 5 \\
\hline $\begin{array}{l}2015 \text { - Launched Small Business Access to } \\
\text { Capital Initiative }\end{array}$ & 5 & $\begin{array}{l}\text { on-going - collaborate with groups that } \\
\text { support diverse-owned businesses }\end{array}$ & 4 \\
\hline $\begin{array}{l}2015 \text { - doubled efficiency of their fleets - } \\
\text { saving nearly } 1 \text { billion and prevented } 650,000 \\
\text { metric tons of emissions in } 2015\end{array}$ & 8 & $\begin{array}{l}\text { ongoing - supports two organizations } \\
\text { for women-owned businesses }\end{array}$ & 3 \\
\hline $\begin{array}{l}2017 \text { - cornell university grant to train apple } \\
\text { growers in china }\end{array}$ & 8 & $\begin{array}{l}2017 \text { - partnered with Endeavor Global } \\
\text { to train women entrepreneurs } \\
\text { internationally }\end{array}$ & 3 \\
\hline $\begin{array}{l}2025 \text { - achieve zero waste in US, Canada, UK, } \\
\text { and Japan }\end{array}$ & 8 & $\begin{array}{l}2017 \text { - helped fund Women } \\
\text { Development Program in India }\end{array}$ & 3 \\
\hline on-going - studying waste in different markets & 7 & $\begin{array}{l}\text { on-going - Sam's Club Giving Program } \\
\text { supports a variety of causes, particularly } \\
\text { small businesses }\end{array}$ & 4 \\
\hline $\begin{array}{l}\text { on-going - shifting to reusable packing } \\
\text { containers - } 50 \% \text { in produce }\end{array}$ & 6 & $\begin{array}{l}\text { ongoing - Member of Renewable } \\
\text { Energy Buyers Principles }\end{array}$ & 5 \\
\hline $\begin{array}{l}2017 \text { - require suppliers to send clothing in } \\
\text { thinner plastic bags }\end{array}$ & 6 & ongoing - member - RE100 & 6 \\
\hline $\begin{array}{l}2017 \text { - saved } 25,000 \text { trees by switching to } \\
\text { e-prescriptions }\end{array}$ & 7 & $\begin{array}{l}2016-1 \text { million acres of wildlife } \\
\text { protected }\end{array}$ & 6 \\
\hline
\end{tabular}




\begin{tabular}{|c|c|c|c|}
\hline $\begin{array}{l}2017 \text { - program to encourage suppliers to } \\
\text { report and increase the diversity of their teams } \\
\text { supporting Walmart }\end{array}$ & & $\begin{array}{l}\text {-2019 - } 20 \text { million invested to help } \\
\text { veterans reintegrate into society }\end{array}$ & 4 \\
\hline $\begin{array}{l}2025 \text { - reduce emissions by } 18 \% \text { of } 2015 \\
\text { levels }\end{array}$ & 7 & $\begin{array}{l}2016 \text { - } 100 \text { million in giving over } 5 \\
\text { years to increase economic mobility } \\
\text { among retail workers }\end{array}$ & 4 \\
\hline $\begin{array}{l}2030 \text { - work with suppliers to eliminate } 1 \\
\text { gigaton of emissions from production }\end{array}$ & 7 & $\begin{array}{l}2016 \text { - } 1 \text { million females trained } \\
\text { worldwide }\end{array}$ & 2 \\
\hline $\begin{array}{l}2025 \text { - upgrade all heating, refrigerating, and } \\
\text { cooling systems }\end{array}$ & 6 & $\begin{array}{l}2016 \text { - } 1.25 \text { million associate volunteer } \\
\text { hours }\end{array}$ & 4 \\
\hline on-going - improve truck fleet technology & 8 & $\begin{array}{l}2016-800+\text { scholarships for associates } \\
\text { and dependents }\end{array}$ & 6 \\
\hline $\begin{array}{l}2017 \text { - solar powered } 90 \% \text { of buildings in } \\
\text { India }\end{array}$ & 6 & $\begin{array}{l}2016 \text { - } 39 \text { million invested in Retail } \\
\text { Opportunity Initiative }\end{array}$ & 6 \\
\hline $\begin{array}{l}2017 \text { - partnered with Tesla to create solar } \\
\text { energy storage at } 18 \text { stores in CA }\end{array}$ & 7 & $\begin{array}{l}2016 \text { - } 122 \text { million to date invested in } \\
\text { women empowerment }\end{array}$ & 3 \\
\hline 2017 - 300 electric car charging stations & 7 & $\begin{array}{l}2016 \text { - invested } 3 \text { million in Goodwill's } \\
\text { Careers in Retail Initiative }\end{array}$ & 3 \\
\hline $\begin{array}{l}2017 \text { - reduced energy usage by } 12 \% \text { of } 2010 \\
\text { levels }\end{array}$ & 7 & $\begin{array}{l}2016 \text { - 600,000 dollar grant to Hope } \\
\text { Street Group }\end{array}$ & 1 \\
\hline $\begin{array}{l}2015 \text { - installed 5,919 high efficiency rooftop } \\
\text { heating and cooling units }\end{array}$ & 6 & $\begin{array}{l}2015 \text { - } 11 \text { million invested in Chicago } \\
\text { Cook Workforce Partnership }\end{array}$ & 2 \\
\hline $\begin{array}{l}\text { on-going - Brazil Walmart Institute to train } \\
\text { workers }\end{array}$ & 6 & $\begin{array}{l}2015 \text { - } 1 \text { million dollar grant to Institute } \\
\text { for Veterans and Military Families }\end{array}$ & 2 \\
\hline 2009-2015 - doubled sales of local produce & 8 & 2016 - Greenlight a Veteran campaign & 2 \\
\hline $2016-13,000$ veterans promoted & 6 & $\begin{array}{l}2015 \text { - donated } 1 \text { million to Fisher } \\
\text { House Foundation }\end{array}$ & 1 \\
\hline 2016 - raised entry level wages & 7 & $\begin{array}{l}\text { 2016- } \$ 150,000 \text { to Wreaths Across } \\
\text { America to honor vets }\end{array}$ & 2 \\
\hline $\begin{array}{l}2016 \text { - } 6 \text { month training program for all new } \\
\text { employees to increase economic mobility }\end{array}$ & 6 & $\begin{array}{l}2016 \text { - funded a business course for } \\
\text { women entrepreneurs }\end{array}$ & 2 \\
\hline $\begin{array}{l}2016 \text { - lifelong subsidized learning program } \\
\text { enables employees to learn languages, get } \\
\text { college credit and take college courses and } \\
\text { little or no cost. }\end{array}$ & 6 & $\begin{array}{l}\text { on-going - partnered with several } \\
\text { diversity-owned business organizations }\end{array}$ & 3 \\
\hline $\begin{array}{l}2016 \text { - new flexible scheduling options for } \\
\text { employees }\end{array}$ & & $\begin{array}{l}\text { 2011-2016 } 28 \text { million in grants to } \\
\text { organizations that support local } \\
\text { businesses }\end{array}$ & 4 \\
\hline $\begin{array}{l}2016 \text { - training for managers on how to lead } \\
\text { diverse teams }\end{array}$ & 6 & $\begin{array}{l}\text { ongoing - supports Accion Network for } \\
\text { small businesses }\end{array}$ & 4 \\
\hline
\end{tabular}




\begin{tabular}{|c|c|c|c|}
\hline $\begin{array}{l}\text { on-going - guarantees jobs for veterans and } \\
\text { spouses when the military relocates them }\end{array}$ & 7 & $\begin{array}{l}\text { on-going - Partnered with Field to } \\
\text { Market to improve agriculture practices }\end{array}$ & 6 \\
\hline $\begin{array}{l}2016 \text { - launched ecommerce platform for } \\
\text { women empowering businesses }\end{array}$ & & $\begin{array}{l}2015-100,000 \mathrm{~kg} \text { of PET materials } \\
\text { recycled by customers at walmart } \\
\text { drop-offs in Argentina }\end{array}$ & 5 \\
\hline $\begin{array}{l}\text { 2013-2023 - purchase } 250 \text { billion worth of } \\
\text { products supporting American jobs }\end{array}$ & 8 & $\begin{array}{l}2016 \text { - signee New York Declaration of } \\
\text { Forests - halving deforestation }\end{array}$ & 1 \\
\hline on-going - women owned product labeling & 8 & $\begin{array}{l}2016 \text { - } 1 \text { million dollar grant to Ducks } \\
\text { Unlimited }\end{array}$ & \\
\hline $\begin{array}{l}2016-8 \% \text { of supplier spending was on } \\
\text { diverse owned businesses }\end{array}$ & 7 & $\begin{array}{l}2016 \text { - provided nutrition education for } \\
1.9 \text { million people }\end{array}$ & 2 \\
\hline $\begin{array}{l}2016 \text { - reduced per square foot energy } \\
\text { intensity by } 10 \% \text { since } 2014\end{array}$ & 7 & $\begin{array}{l}2016 \text { - Helped found US Roundtable for } \\
\text { sustainable beef }\end{array}$ & 6 \\
\hline $\begin{array}{l}2016-77 \% \text { of food suppliers reported } \\
\text { sustainability index }\end{array}$ & 8 & $\begin{array}{l}2015 \text { - } 15 \text { million to help people access } \\
\text { SNAP benefits }\end{array}$ & 8 \\
\hline 2016 - 06 CDP score for disclosing emissions & 7 & on-going - partnered with FoodCorps & 5 \\
\hline $\begin{array}{l}2015 \text { - largest on-site solar energy user in the } \\
\text { US }\end{array}$ & & $\begin{array}{l}\text { ongoing - supports Consumer Goods } \\
\text { Forum }\end{array}$ & 7 \\
\hline $\begin{array}{l}2016-60 \% \text { of Mexico's stores are powered by } \\
\text { renewable energy }\end{array}$ & 6 & $\begin{array}{l}\text { ongoing - supports international justice } \\
\text { mission }\end{array}$ & 4 \\
\hline $\begin{array}{l}\text { ongoing - Climate Smart Agriculture } \\
\text { Platforms - improve supplier sustainability }\end{array}$ & 7 & $\begin{array}{l}\text { on-going - founding member Alliance } \\
\text { for Bangladesh Worker Safety }\end{array}$ & 3 \\
\hline $\begin{array}{l}2016 \text { - trained } 500 \text { factories in China how to } \\
\text { use REDE platform to measure/improve } \\
\text { emissions }\end{array}$ & & $\begin{array}{l}\text { ongoing - partnership Coalition of } \\
\text { Immokalee Workers }\end{array}$ & 3 \\
\hline $\begin{array}{l}\text { ongoing - Smart and Efficient home products } \\
\text { program - marketing those products more }\end{array}$ & & $\begin{array}{l}2016 \text { - helped provide } 27 \text { million school } \\
\text { breakfasts in Canada }\end{array}$ & 3 \\
\hline $\begin{array}{l}\text { on-going - recycle } 3 \text { million tons and counting } \\
\text { globally }\end{array}$ & & $\begin{array}{l}2016 \text { - } 1.2 \text { million UN grant for disaster } \\
\text { preparedness }\end{array}$ & 2 \\
\hline on-going - trade in programs to reduce e-waste & 6 & $\begin{array}{l}2016 \text { - Walmart Japan helped fund the } \\
\text { country's first in-home daycare for } \\
\text { disabled children }\end{array}$ & 4 \\
\hline $\begin{array}{l}\text { on-going - partnered with Metrolina to } \\
\text { recycle/reuse/resell flower containers }\end{array}$ & & $\begin{array}{l}2015 \text { - invested } 15 \text { million in } 7 \\
\text { nonprofits that support retail and related } \\
\text { workers with training and other } \\
\text { resources }\end{array}$ & 5 \\
\hline $\begin{array}{l}\text { ongoing - Soy Moratorium in Brazil to try to } \\
\text { achieve sustainable soy sourcing }\end{array}$ & 7 & & \\
\hline $\begin{array}{l}2016 \text { - made } 80 \text { million clothing labels } \\
\text { sustainable }\end{array}$ & 7 & & \\
\hline
\end{tabular}


on-going - assess supplier packaging and encourages increase sustainability

2015 - onward - labeling to teach customers how to recycle products

2015 - saved 22.3 million pounds of cardboard from shipping clothes and shoes

ongoing - only purchase sustainable palm oil products

2015 - achieved - 100\% of beef not contributing to Amazon deforestation

2020 - achieve zero net deforestation

2016 - Walmart Japan reduced water usage by $30 \%$

2016 - Walmart Mexico recycled 32\% of water

2016 - Hayden Meadows has largest eco-roof in the country

2016 - reduced sugar and salt and eliminated trans fat from their private brand foods

2016 - saved customers over 6 billion dollars over 5 years on fresh produce

2011-2016 - opened 442 stores in food deserts

2016 - switched to best if used by dates and eliminated an estimated 600 million pounds of food waste

$2016-100 \%$ of seafood is sustainably sourced

$2016-76 \%$ of sustainability-indexed suppliers posted their ingredients online

on-going - requires suppliers to abide by strict worker safety and respect guidelines

2010-2017 - auto and cooking oil recycling generated 147 million in revenue

2015 - pays $60 \%$ of associate medical plans above retail average

$2015-100 \%$ preventative care coverage

2015 - developed cleaning products that reduce plastic waste by $80 \%+$

2013 - reduced plastic bag waste by $38.1 \%$

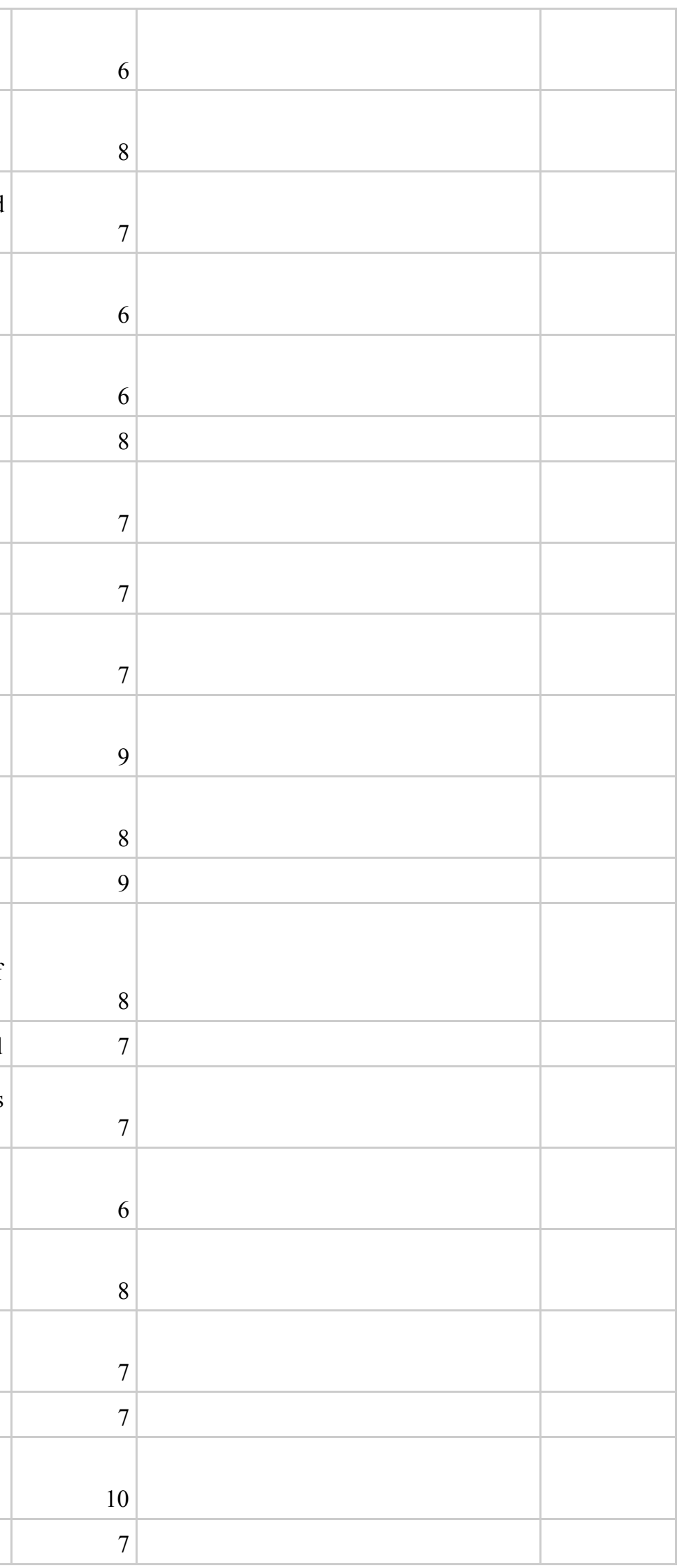




\begin{tabular}{|c|c|c|}
\hline $\begin{array}{l}2013 \text { - reduced } 2.1 \text { million metric tons of } \\
\text { greenhouse gases from the supply chain }\end{array}$ & 7 & \\
\hline $\begin{array}{l}2014 \text { - sourced } 4 \text { billion dollars worth of } \\
\text { product from small and medium-sized farms. }\end{array}$ & 8 & \\
\hline ongoing - fund research on retail workers & 6 & \\
\hline on-going - 100,000 Opportunities partnership & 7 & \\
\hline
\end{tabular}

Intel

\begin{tabular}{|c|c|c|c|}
\hline Internal Strategies & Scores & External Strategies & Scores \\
\hline 2016 - 555 million spent with diverse suppliers & 8 & $2016-1.27$ million in charitable giving & 4 \\
\hline 2016 - 57 billion gallons of water saved since 1998 & 8 & $\begin{array}{l}2016 \text { - } 1.2 \text { million employee volunteer } \\
\text { hours }\end{array}$ & 4 \\
\hline $\begin{array}{l}2016-100 \% \text { green US power, } 80 \% \text { green global } \\
\text { power }\end{array}$ & 7 & $\begin{array}{l}2016 \text { - } 25 \text { million invested in } \\
\text { diversity-focused technology career } \\
\text { pathways }\end{array}$ & 5 \\
\hline $\begin{array}{l}\text { 2008-ongoing - portion of compensation is linked } \\
\text { to CSR }\end{array}$ & 8 & $\begin{array}{l}\text { on-going - as of } 20161.39 \text { million women } \\
\text { in Africa reached via She Will Connect } \\
\text { Program }\end{array}$ & 6 \\
\hline $\begin{array}{l}\text { 2000-ongoing - met with investors and other } \\
\text { parties to help evaluate/get feedback on their CSR } \\
\text { strategies }\end{array}$ & & $\begin{array}{l}\text { ongoing - Intel Capital Diversity Fund - } \\
\text { largest venture capital fund to focus on } \\
\text { diverse entrepreneurs }\end{array}$ & 5 \\
\hline $\begin{array}{l}2016 \text { - developed a smart bangle for women in } \\
\text { India to detect dangerous levels of carbon } \\
\text { monoxide }\end{array}$ & 10 & ongoing - member EICC & 7 \\
\hline $\begin{array}{l}2016 \text { - collaborated with GE to create smart } \\
\text { lighting that is more efficient/ optimizes itself to } \\
\text { use less electricity based on what a space needs }\end{array}$ & 10 & $\begin{array}{l}\text { ongoing - intel education accelerator } \\
\text { program to fund technology that improves } \\
\text { education }\end{array}$ & 6 \\
\hline 2016 - decrease emissions by $6 \%$ per unit of 2015 & 7 & $\begin{array}{l}\text { on-going - participates in several } \\
\text { climate-focused organizations }\end{array}$ & 4 \\
\hline $\begin{array}{l}2016 \text { - increase on-site green energy installations } \\
\text { by nearly } 50 \%\end{array}$ & 6 & $\begin{array}{l}\text { on-going - host global events to help } \\
\text { diverse businesses thrive }\end{array}$ & 5 \\
\hline 2012-2016 - saved 2.3 billion kwh & 7 & $\begin{array}{l}2016 \text { - } 25 \text { million invested in STEM } \\
\text { education }\end{array}$ & 6 \\
\hline 2016 - less than $1 \%$ hazardous waste to landfill & 7 & $\begin{array}{l}2016 \text { - launched Future Skills program to } \\
\text { teach kids tech skills }\end{array}$ & 7 \\
\hline 2016 - recycled $82 \%$ of non-hazardous waste & 7 & $\begin{array}{l}\text { 1999-2016 - } 2 \text { billion invested in higher } \\
\text { education }\end{array}$ & 6 \\
\hline $\begin{array}{l}\text { 2011-2016 - increased LEED certified square } \\
\text { footage by } 126 \%\end{array}$ & 6 & $\begin{array}{l}\text { 2010-2016 - } 70 \text { million volunteer } \\
\text { matching grants }\end{array}$ & 4 \\
\hline 2016 - audits for $100 \%$ of top 75 suppliers & 7 & $\begin{array}{l}\text { on-going - partnered with Society for } \\
\text { Science and the Public }\end{array}$ & 6 \\
\hline
\end{tabular}




\begin{tabular}{|c|c|c|c|}
\hline $2016-73 \%$ green ground transport & 7 & 2016 - 500,000 dollars for hurricane relief & 1 \\
\hline $\begin{array}{l}2016-80 \% \text { of water is treated and returned to } \\
\text { communities }\end{array}$ & 6 & $\begin{array}{l}\text { ongoing - Intel Employee Service Corps - } \\
\text { employees train to go to rural areas and } \\
\text { implement intel technology }\end{array}$ & 7 \\
\hline $\begin{array}{l}\text { on-going - invests in on-site biodiversity by } \\
\text { maintaining many acres of wildlife land on/near } \\
\text { campuses }\end{array}$ & 8 & $\begin{array}{l}\text { ongoing - Intel International Science and } \\
\text { Engineering Fair }\end{array}$ & 7 \\
\hline $\begin{array}{l}\text { ongoing - sustainability leaders speaker series to } \\
\text { inform employees about sustainability efforts }\end{array}$ & 5 & 2016 - women in science camp in peru & 4 \\
\hline $\begin{array}{l}2016 \text { - reduced the energy needed to mount chips } \\
\text { by } 40 \%\end{array}$ & 9 & $\begin{array}{l}2016 \text { - } 167,000 \text { hours of skills-based } \\
\text { volunteering }\end{array}$ & 5 \\
\hline $\begin{array}{l}2016 \text { - transformed } 40 \% \text { of difficult to treat water } \\
\text { waste into fuel }\end{array}$ & 10 & $\begin{array}{l}\text { on-going - train retiring employees to } \\
\text { work in nonprofits }\end{array}$ & 3 \\
\hline $\begin{array}{l}2015-2016 \text { - } 140 \text { tons of an unused chemical sent } \\
\text { to secondary industries }\end{array}$ & 7 & $\begin{array}{l}2016 \text { - 550,000 worth of grants to support } \\
\text { employee-initiated projects }\end{array}$ & 6 \\
\hline $\begin{array}{l}\text { on-going - highly technologically green optimized } \\
\text { buildings }\end{array}$ & 8 & $\begin{array}{l}2016 \text { - created a course for students in } \\
\text { oregon }\end{array}$ & 5 \\
\hline $\begin{array}{l}2020 \text { - green chemistry screening for } 100 \% \text { of new } \\
\text { chemicals and gases }\end{array}$ & 7 & $\begin{array}{l}2016 \text { - setting up solar lights for sports } \\
\text { parks in Ireland }\end{array}$ & 4 \\
\hline $\begin{array}{l}2017 \text { - goal for } 90 \% \text { of suppliers to pass their } \\
\text { sustainability standards }\end{array}$ & 6 & $\begin{array}{l}2016 \text { - training } 1500 \text { Chinese teachers and } \\
\text { school children on disaster preparedness }\end{array}$ & 1 \\
\hline ongoing - efforts to prevent and stop forced labor & 6 & $\begin{array}{l}2016 \text { - creating a greenhouse to provide } \\
\text { student lunches in Arizona }\end{array}$ & 2 \\
\hline on-going - pursuing conflict-free minerals & 7 & $\begin{array}{l}\text { on-going - serves on the board of the green } \\
\text { grid }\end{array}$ & 5 \\
\hline $\begin{array}{l}2014-2016-3.5 \text { million dollars in fees returned } \\
\text { to workers }\end{array}$ & 7 & $\begin{array}{l}2014 \text { - donated } 43,000 \text { development } \\
\text { boards to } 1,900 \text { universities }\end{array}$ & 5 \\
\hline $\begin{array}{l}2016-83 \% \text { of participating sustainability } \\
\text { assessment suppliers passed objectives }\end{array}$ & 6 & $\begin{array}{l}\text { ongoing - sustainability in action grant } \\
\text { program for employees to do their own } \\
\text { projects }\end{array}$ & 8 \\
\hline 2016 - audits for $100 \%$ of top 75 suppliers & 6 & $\begin{array}{l}2004 \text { - } 2014 \text { - invested } 10 \text { billion to } \\
\text { improve education around the world }\end{array}$ & 5 \\
\hline on-going - supplier sustainability resource center & 8 & $\begin{array}{l}2014 \text { - providing training to } 1 \text { million } \\
\text { healthcare workers in developing countries }\end{array}$ & 1 \\
\hline $\begin{array}{l}\text { on-going - face-to-face supplier sustainability } \\
\text { workshop }\end{array}$ & 8 & $\begin{array}{l}\text { as of } 2014-\text { led } 300+\text { programs in } 100 \\
\text { countries to help teachers teach stem }\end{array}$ & 6 \\
\hline $\begin{array}{l}\text { ongoing - partners with other tech companies to } \\
\text { pressure suppliers to treat employees fairly }\end{array}$ & 6 & $\begin{array}{l}\text { 1999-2014 - helped } 15 \text { million+ teachers } \\
\text { integrate technology in their classrooms }\end{array}$ & 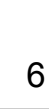 \\
\hline
\end{tabular}


2015 - 300 million investment for equal representation of women

on-going - employee resource groups for diverse employees

on-going - pay promotion and equity for women and diverse employees

$2020-10 \%$ of supplier spending on behalf of intel will be on diverse-owned businesses

on-going - partnered with WEConnect to certify global suppliers

on-going - pay for small diverse owned suppliers to attend conferences

2020 - increase notebook and data center product energy efficiency $25 x$ from 2010 levels

2020 - full representation of women and minorities on-going as of 2014 - plan to invest 300 million in helping tech careers for women and minorities

since 2008 - recycled $75 \%$ of waste generated in operations

on-going - biodiversity projects at several plants 2014 - winning intel team projects saved 5,000 tons of waste. $29 \mathrm{mkw}$ of energy, 53,000 metric tons of co2 and saved the company 50 million dollars

ongoing - supports employee sustainability groups

2014 - developed sleep mode for semiconductor manufacturing to save energy when not in use on-going - working to eliminate shipping waste ongoing - purchases renewable energy certificates to reduce absolute energy emissions

1990s - eliminated use of ozone-depleting substances

2014 - 30 million for resource conservation and energy efficiency

2014 - 20 new solar installations ongoing - fund various afterschool stem

6 programs

ongoing - partner with Girl Rising to

expand awareness of need for female

7 education

on-going - partnered with a variety of

7 other female tech orgs

on-going - provides technical support for

8 non profit initiatives

2014 - 23.4 million donated through employee/retiree giving match program

7 (split)

2013 - sponsored 3 hackathons focused on

7 climate data

on-going - improve electronic waste

7 recycling and disposal

2003 - present - Intel Learn program for

8 underserved kids

2013 - sponsored social innovation week 6 in china

2013 - 24 million in employee matching

7 giving program

2013 - through mcafee created a course to

7 educate kids about online safety

2013 - partnered with nonprofits to

9 provide water education resources

ongoing - supports various social

7 entrepreneurship programs

on-going - supporting bee hives in

10 california

\begin{tabular}{|c|c|}
\hline \multicolumn{2}{|c|}{7} \\
\hline 6 & \\
\hline 7 & \\
\hline 6 & \\
\hline 6 & \\
\hline
\end{tabular}




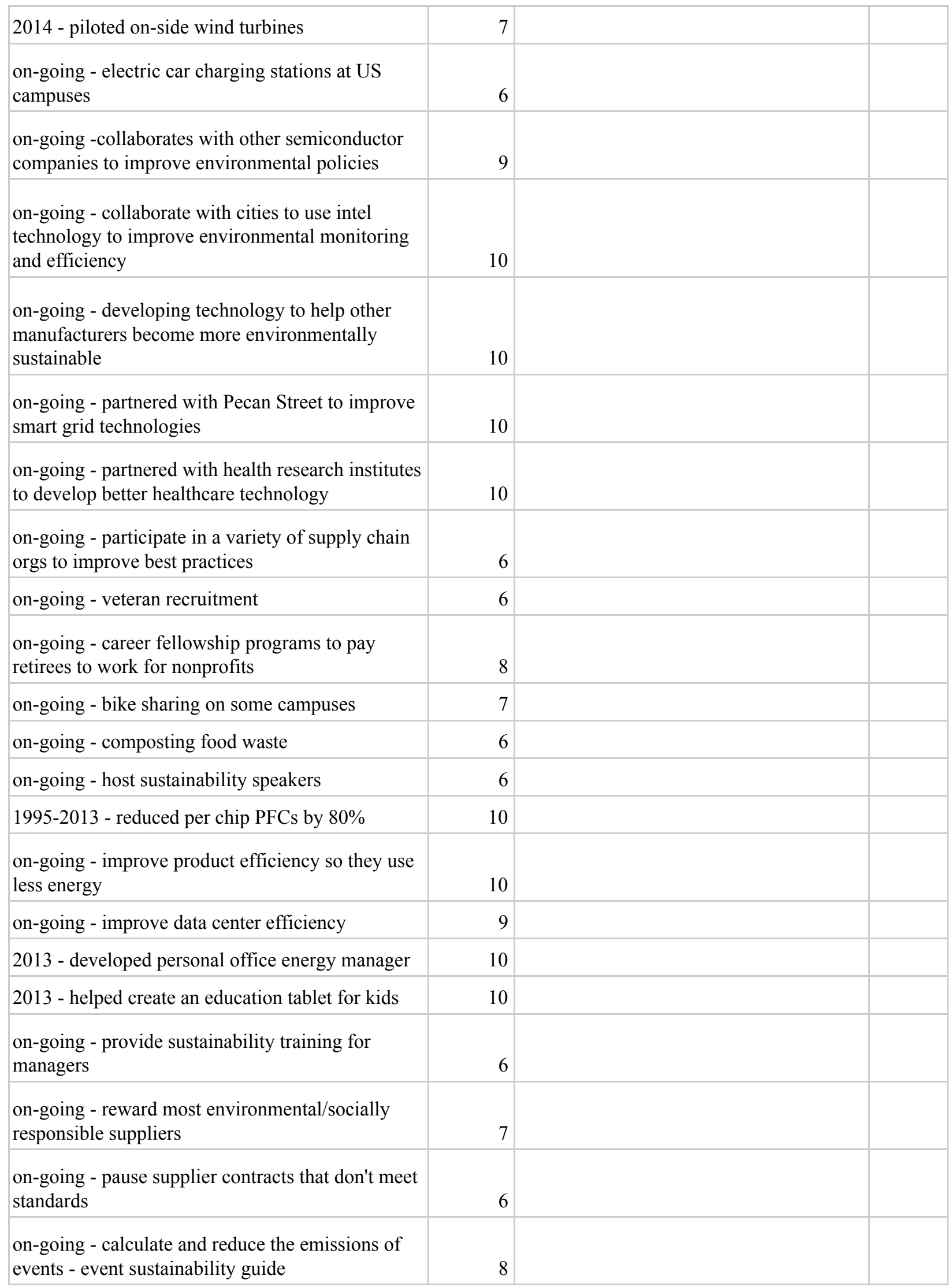


on-going - special audits for conflict mineral suppliers

Nike

\begin{tabular}{|c|c|c|c|}
\hline Internal Strategies & Scores & External Strategies & Scores \\
\hline $\begin{array}{l}14 / 15 \text { - recycled materials used in } 71 \% \text { of } \\
\text { shoes and apparel }\end{array}$ & 9 & $\begin{array}{l}\text { on-going - founding members of open } \\
\text { innovation platform LAUNCH }\end{array}$ & 7 \\
\hline $14 / 15$ - per unit emissions decreased by $19 \%$ & 8 & $\begin{array}{l}\text { on-going - invest a minimum of } 1.5 \% \text { of } \\
\text { pre-tax income in getting kids active }\end{array}$ & 8 \\
\hline $2025-100 \%$ renewable energy & 8 & on-going - partnered with NASA & 4 \\
\hline $\begin{array}{l}\text { 14/15 - } 29 \text { high performance materials made } \\
\text { from manufacturing waste }\end{array}$ & 10 & 2015 - joined RE100 & 7 \\
\hline $\begin{array}{l}\text { on-going - very comprehensive csr focus } \\
\text { identification assessment - starts with } 400 \\
\text { issues and narrowed them down }\end{array}$ & 7 & $\begin{array}{l}\text { 2010-2014 - helped build Designed to Move } \\
\text { campaign }\end{array}$ & 7 \\
\hline $\begin{array}{l}2020 \text { - zero footwear manufacturing waste } \\
\text { sent to landfills }\end{array}$ & 10 & 14/15 - Developed Active Schools Guide & 5 \\
\hline $\begin{array}{l}2020-80 \%+\text { of products scored on } \\
\text { sustainability }\end{array}$ & 9 & $\begin{array}{l}\text { ongoing - supports youth sports across the } \\
\text { globe }\end{array}$ & 6 \\
\hline $\begin{array}{l}2020 \text { - decrease emissions by } 25 \% \text { for key } \\
\text { operations }\end{array}$ & 8 & ongoing - Nike School Innovation Fund & 5 \\
\hline $\begin{array}{l}2020 \text { - decrease energy and emissions } 35 \% \\
\text { for textile dyeing and finishing processes }\end{array}$ & 9 & $\begin{array}{l}\text { ongoing - Nike Community Ambassador } \\
\text { Program }\end{array}$ & 4 \\
\hline $\begin{array}{l}2020 \text { - reduce waste by } 5 \% \text { per unit in key } \\
\text { operations }\end{array}$ & 8 & $14 / 15$ - 48,000 volunteer hours & 4 \\
\hline $\begin{array}{l}2020 \text { - return } 100 \% \text { of wastewater cleaner } \\
\text { than required by local law }\end{array}$ & 7 & $\begin{array}{l}\text { on-going - donates to causes when employees } \\
\text { volunteer }\end{array}$ & 4 \\
\hline $\begin{array}{l}2020-100 \% \text { compliance with NIke and } \\
\text { ZDHC restricted substances (chem) }\end{array}$ & 9 & $\begin{array}{l}\text { ongoing - matches employee giving - } 6.2 \\
\text { million in } 14 / 15\end{array}$ & 4 \\
\hline $\begin{array}{l}2020-100 \% \text { of factories will meet their } \\
\text { definition of sustainable }\end{array}$ & 8 & on-going - partnered with UNESCO & 3 \\
\hline $\begin{array}{l}\text { on-going - work to ensure factory workers are } \\
\text { fairly compensated }\end{array}$ & 6 & 15 - launched Girl Effect & 6 \\
\hline $\begin{array}{l}2012 \text { - flyknit reduces shoe production waste } \\
\text { by } 60 \%\end{array}$ & 10 & $\begin{array}{l}15 \text { - helped launch Business for Innovative } \\
\text { Climate and Energy Policy }\end{array}$ & 6 \\
\hline $\begin{array}{l}\text { on-going - world's largest user of recycled } \\
\text { polyester - } 39 \% \text { of garments contain it }\end{array}$ & 9 & $\begin{array}{l}15 \text { - partnered with MIT to make materials at } \\
\text { the forefront of climate conversations }\end{array}$ & 6 \\
\hline $\begin{array}{l}\text { ongoing - fabric made of plastic bottles - } 3 \\
\text { billion between } 2012 \text { - } 2016\end{array}$ & 10 & ongoing - supports the Paris Agreement & 5 \\
\hline
\end{tabular}


2015 - colordry saved 20 million liters of water

$2015-26+\%$ sustainable cotton on-going - materials sustainability index rates 57,000 materials to help teams choose the best ones

2020 - cut carbon impact of products by an avg of $10 \%$

2020 - $100 \%$ sustainable cotton

$2015-76 \%$ of shoes used sustainable rubber

2008 - 2015 - factories cut energy per footwear unit in half

on-going - majority of new Nike stores LEED certified

2015 - 20\% reduction in footwear manufacturing emissions

2015 - 9\% reduction in inbound logistics emissions

$2015-13 \%$ reduction in emissions per square foot of retail stores

2015 - 3\% absolute emissions reduction at headquarters

2010-2015 - 96\% of footwear volume came from suppliers participating in Nike Energy and Carbon Program

$2015-49 \%$ of headquarters emissions offset by renewable certificates

1990 - 2015 - collected and recycled 30 million pairs of used shoes

ongoing - nike grind (scrap) materials have been turned into 1 million square feet of sports surfaces (ex tracks)

$2015-6.3 \%$ reduction in shoe box weight better box program

2015 - $6 \%$ reduction in waste on-going - collaborates with the Sustainable

10 Apparel Coalition

on-going - advising member fair labor

8 association

on-going - sponsor/collaborate with various

10 innovative and healthy living programs

on-going - leverages brand power to support

7 existing initiatives

6 12/13 - donated for disaster relief

6 disadvantaged groups

10/11 - provided filtration systems for 75

6 million remote people

7 10/11 - RED partnership to support AIDs

Donates approximately 50 million dollars a

6 year to various causes. ongoing - supports lots of active programs for

7

7

8

6

8

8 7

6 


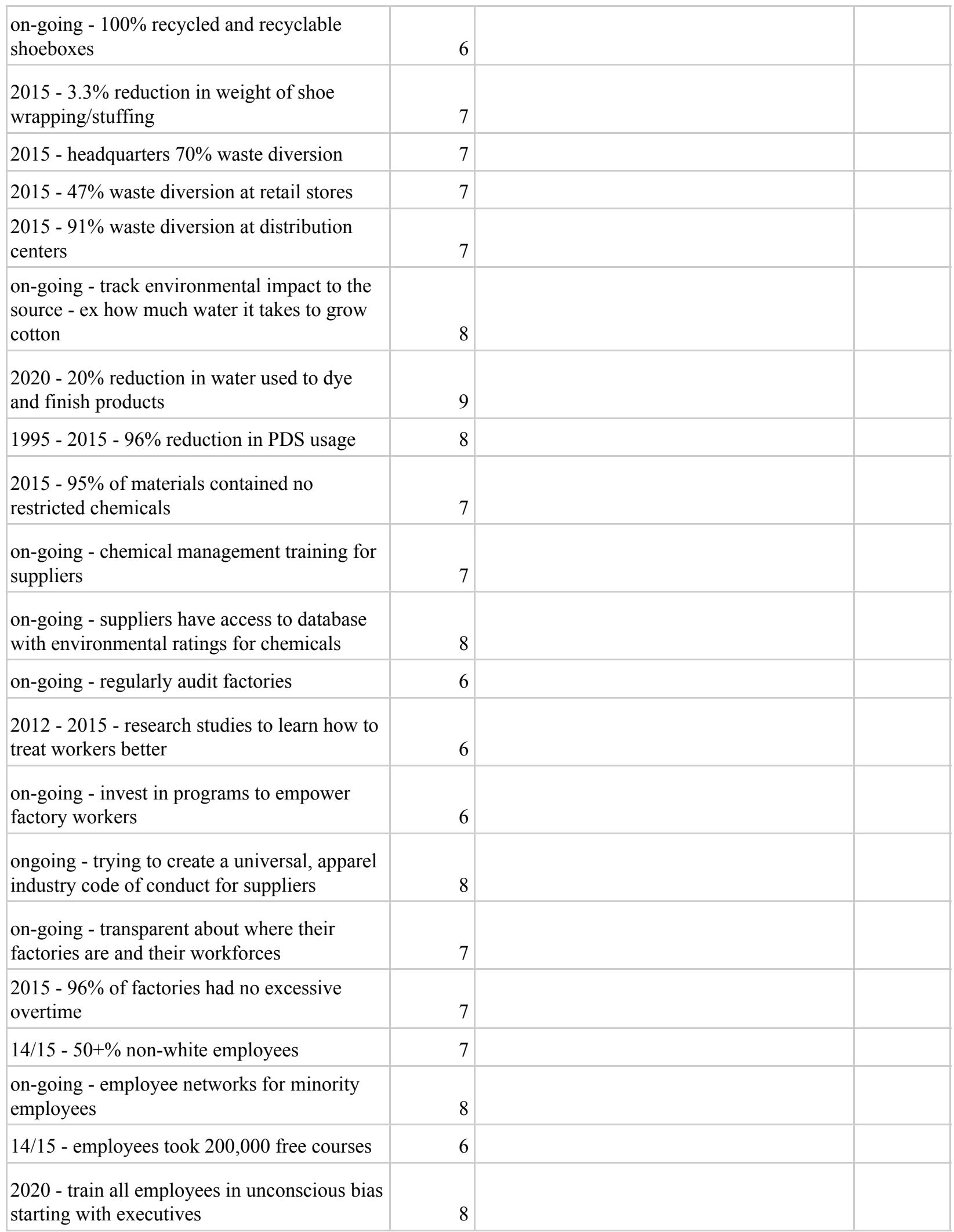


12/13 - developed BEST (Business and Environmental Scenario Tool) to create 10 year forecasts of financial and environmental impacts

13 - hosted a summit to discuss sustainable materials innovation with the government and other manufacturers

13 - $10 \%$ water reduction apparel

$13-23 \%$ water reduction footwear

on-going - committed to measuring impact of social investments

$12 / 13-29 \%$ reduction in inbound transportation co 2

$12 / 13-26 \%$ per unit energy reduction in distribution centers

$12 / 13-16 \%$ energy reduction per square foot in headquarters

$12 / 13-17 \%$ reduction in co2 per unit of footwear

13 - offset $46 \%$ of energy in north american retail stores with renewable energy certificates

$12 / 13$ - overall energy used in supply chain reduced by $5 \%$

$12 / 13$ - overall supply chain emissions dropped by $2.8 \%$

$13-77 \%$ of north american retail stores have energy management systems

$13-82 \%$ of contract factories had grievance systems

on-going - holds suppliers accountable for improving worker safety

ongoing - surveys to give factory workers a say in improvements

on-going - highly transparent about their materials and environmental impacts

12/13 - partnered with blue sign certified chemical formulations

2015 - phasing out PFCs

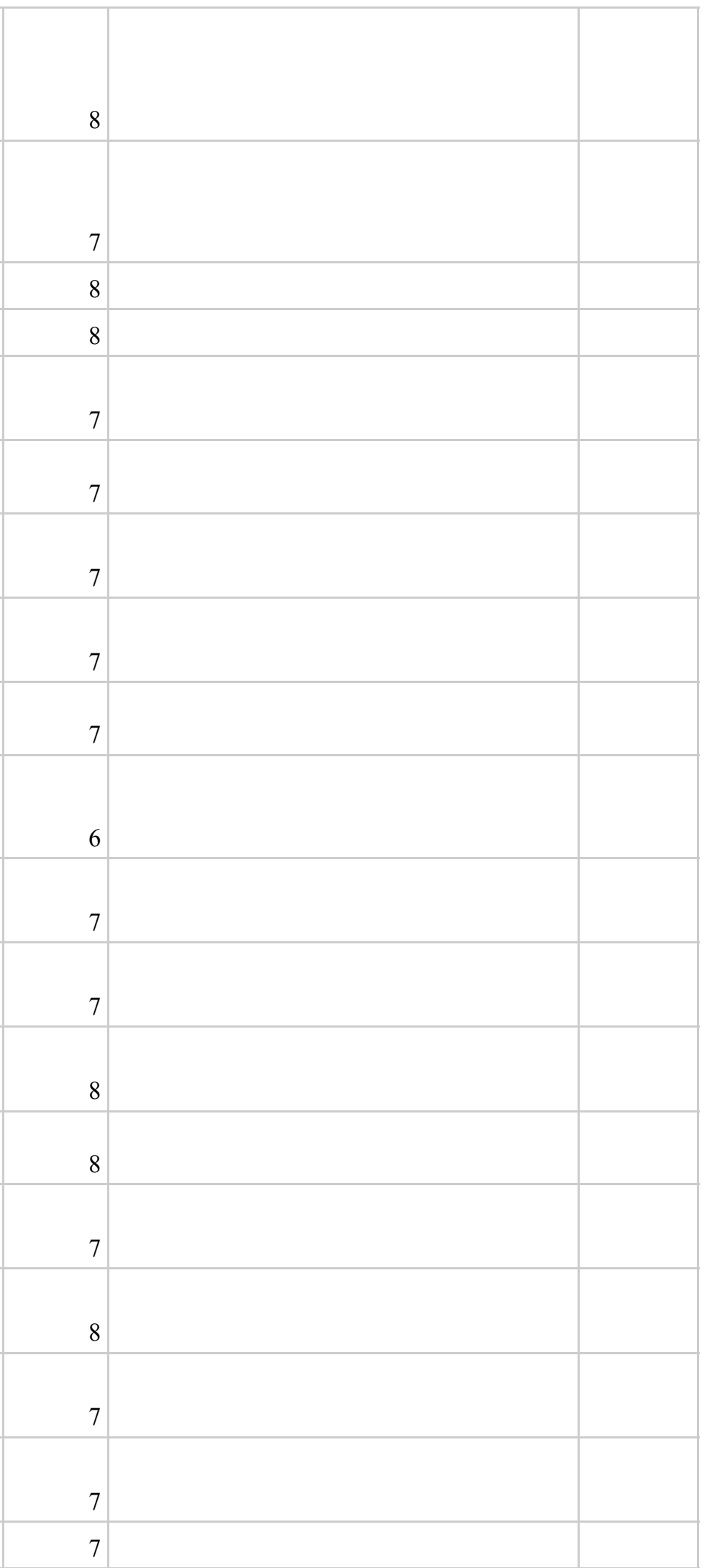


2013 - reduced water per pair of shoes by $23 \%$ in factories

$13-85 \%$ waste diversion in footwear manufacturing

on-going - teams in place to develop tools and help other teams become more sustainable

on-going - collaborating with other companies to develop a scalable, plant-based plastic

$12 / 13$ - engages third parties in helping them create a more inclusive culture

on-going - csr board of directors committee

on-going - contributes and learns from green xchange idea marketplace

on-going - education programs in contract factories

on-going - rate material vendors in addition to materials in their materials sustainability index

2005-2009 - 77\% increase in use of environmentally preferred materials

ongoing - forces suppliers to provide a stable, fairly paid work environment

10/11 - phased out one greenhouse gas $10 / 11$ - automated $85 \%$ of climate data collection in north america

on-going - encourages their suppliers to use more sustainable suppliers

on-going - funds and participates in research to move the industry forward

2010 - put 400 patents under creative license to help others leverage sustainable innovation 13 - made $\mathrm{H} 2 \mathrm{O}$ insight tool available to the industry

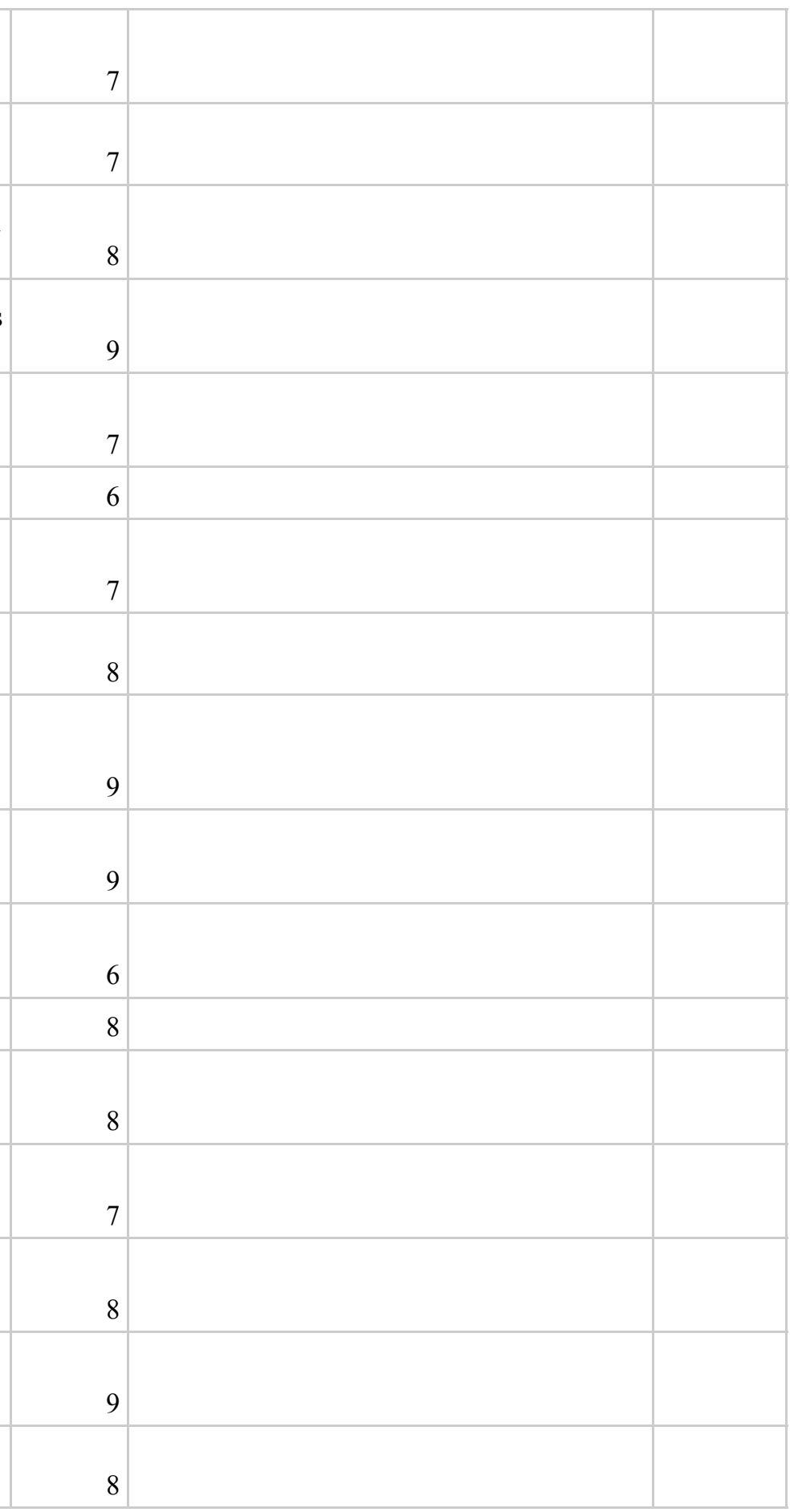

Appendix D

Complete List of B-Corp Strategies and Scores 
uses only an environmentally-prefered form of bamboo fabric

Uses Forest Stewardship certified eucalyptus wood material

limits sourcing of materials that contains harmful chemicals

minimize product packaging

Uses recycled nylon

Design for recyclability

Uses organic cotton

Uses hemp

Uses recycled polyester

Fleece made of recycled soda bottles

$100 \%$ recycled down

recycled wool

zero dyes added to recycled wool products

Forest Stewardship Certified rubber alternative to petroleum based material in wetsuits

uses reclaimed cotton

denim dyeing process that uses $84 \%$ less water

denim dyeing process that uses $30 \%$ less energy and has $25 \%$ lower emissions

denim jeans fair-trade certified for sewing

denim jeans fair-trade certified for sewing

uses sulfur denim dyes instead of chemicals

uses bluesign to evaluate the environmental impact of their supply chain

investing in developing a better waterproofing chemical

develops products with long lifetimes

develops and uses medically safe materials
9 education, not greenwashing marketing strategies

9 encourage customers to use biodegradable detergents

$1 \%$ of sales to support environmental organizations

9 across the world

9 Tools Conference to help activists be more effective

Black Friday - donated $100 \%$ of sales to

9 environmental groups

38 million donated in pro-environmental companies

10 through their venture capital fund

Helped prevent mega dams from being built in two

8 Chilean rivers

$\$ 157,000$ donated through employee giving match

9 program

9 14,000 hours volunteered

$10 \$ 300,000$ worth of clothes donated

Small-grant program to solve local environmental issues - grants given to 824 environmental groups in 92016

9 Advocates to protect natural areas

10 Help fund a national park in Patagonia

\begin{tabular}{r|r}
7 \\
\hline \\
\hline
\end{tabular}

1

10 Advocates for more regulations on crude oil

9 Advocates for paid-family leave

Teamed up with other outdoor brands to form the

10 Conservation Alliance

10 Partnered with NSF international

7 Produces environmental awareness films

Created a fund to make solar energy accessible to 10 1,600 American households

Farm to Market program in Lake Tahoe help makes 8 locally grown food accessible 


\begin{tabular}{|c|c|c|}
\hline uses recycled silver & 9 & \\
\hline $\begin{array}{l}\text { odor-control material application requires no } \\
\text { additional water or energy }\end{array}$ & 10 & \\
\hline $\begin{array}{l}\text { develop products that can be washed at a lower } \\
\text { temperature less often }\end{array}$ & 9 & \\
\hline $\begin{array}{l}\text { produces dyes made with non-vegan natural } \\
\text { ingredients }\end{array}$ & 10 & \\
\hline $\begin{array}{l}\text { produces dyes made of } 96 \% \text { renewable plant-based } \\
\text { materials }\end{array}$ & 10 & \\
\hline certified traceable down & 8 & \\
\hline uses suppliers that are bluesign certified & 8 & \\
\hline uses suppliers that are iso certified & 8 & \\
\hline uses other types of post-consumer recycled fibers & 9 & \\
\hline uses a limestone version of a petrochemical product & 10 & \\
\hline uses chlorine-free wool & 9 & \\
\hline working to eliminate 2 fluorochemicals & 10 & \\
\hline investing in research for sustainable bioplastics & 10 & \\
\hline PVC-free inks & 10 & \\
\hline Collects their clothes for reuse, repair and recycling & 9 & \\
\hline transparent factory list available & 7 & \\
\hline Factory scoring & 8 & \\
\hline member of Fair Labor Association & 6 & \\
\hline Patagonia Supplier Workplace Code of Conduct & 7 & \\
\hline equal pay for equal work policy & 7 & \\
\hline Member - International Labor Organization & 6 & \\
\hline $\begin{array}{l}\text { working to increase raw material production in the } \\
\text { US }\end{array}$ & 8 & \\
\hline Contracts to nine United States factories & 8 & \\
\hline conducts life cycle analysis for products & 9 & \\
\hline $\begin{array}{l}\text { Buys recycled, Forest Stewardship Council Certified } \\
\text { paper }\end{array}$ & 8 & \\
\hline $\begin{array}{l}\text { Catalogs are printed on the lightest weight of paper } \\
\text { feasible }\end{array}$ & 8 & \\
\hline $\begin{array}{l}\text { Collects and distributes "Good on one side" paper in } \\
\text { offices for reuse }\end{array}$ & 9 & \\
\hline Chlorine-free paper & 8 & \\
\hline
\end{tabular}


Sources from a paper mill that is powered by landfill gas

Garment tags are made from 100\% recycled materials

Sales associates do not automatically give bags, if asked, they give reusable ones.

Advertise in print publications that use recycled paper

$800,000+$ single car rides saved through employee "Drive Less" program

$95 \%$ of waste stream materials recycled at Reno plant

Generous family leave program

On-site childcare

Shares best environmental practices with other companies, even direct competition.

Created a set of three books about pro-environmental business

Actively travel countries and have setups in stores to help people fix clothing.

Purchases food products from regenerative sources

Produces beer using a sustainable hybrid plant

Employee cafe offering mostly locally grown food and that reduces food waste to the greatest extent possible

Hosts a farmer's market at their Ventura campus

Sustainability speakers for employees

Urges employees to cycle to work

Recycled labels, zippers and buttons in certain products

All design features on garments must be purpose-driven to reduce waste

Fund university research to improve the environmental sustainability of their products

Member of the Sustainable Apparel Coalition

Fire safety initiative/training

Encourages suppliers to create healthier soils

Sources locally whenever possible

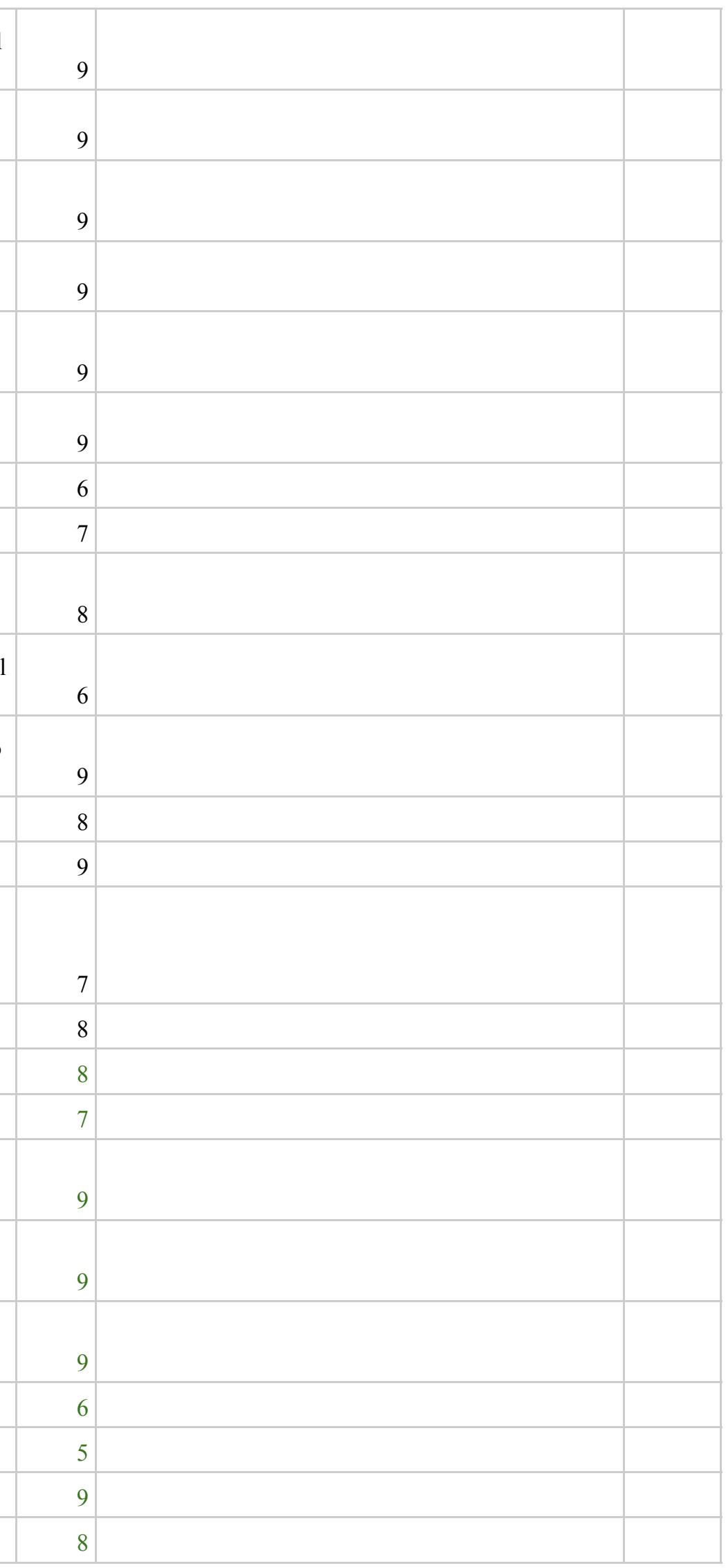




\begin{tabular}{|l|r|r|r|}
\hline $\begin{array}{l}\text { During FY 2015, we generated 203,502 kWh of } \\
\text { on-site renewable energy and purchased 980,112 } \\
\text { kWh of green power }\end{array}$ & 8 & & \\
\hline LEED Gold certified distribution center & 8 & 7 & 8.46987 \\
\hline & 9518 \\
\hline $40 \%$ of workers are women and/or minorities & 8 & & \\
\hline $\begin{array}{l}\text { Guided by Planetary Boundaries - scientific } \\
\text { framework to take actions that help climate change }\end{array}$ & 9 & & \\
\hline Audit 100\% of factories & 8 & \\
\hline $\begin{array}{l}\text { Makes every employee responsible for making the } \\
\text { company more socially responsible }\end{array}$ & 7 & 7 \\
\hline Asks customers to buy fewer products & & \\
\hline Work on fair labor for second-tier suppliers & & \\
\hline
\end{tabular}

\begin{tabular}{|c|c|c|c|c|}
\hline $\begin{array}{l}\text { Ben and } \\
\text { Jerry's }\end{array}$ & Internal Strategies & Scores & External Strategies & Scores \\
\hline & $\begin{array}{l}\text { Caring Dairy plan to help their } \\
\text { suppliers be more sustainable }\end{array}$ & 10 & $\begin{array}{l}\text { Supports mandatory GMO labeling } \\
\text { legislation }\end{array}$ & 6 \\
\hline & $\begin{array}{l}\text { Prioritizes suppliers who use } \\
\text { sustainable agriculture and grazing } \\
\text { practices }\end{array}$ & 8 & $\begin{array}{l}\text { Helps fund climate change advocacy } \\
\text { campaigns }\end{array}$ & 4 \\
\hline & $\begin{array}{l}\text { Requires a higher minimum wage } \\
\text { and protections for dairy farm } \\
\text { workers }\end{array}$ & 9 & $\begin{array}{l}\text { Supports marriage equality around the } \\
\text { world }\end{array}$ & 3 \\
\hline & $\begin{array}{l}\text { Pressures farms to measure and } \\
\text { reduce their emissions }\end{array}$ & 9 & $\begin{array}{l}\text { Sponsored Join Our Core Competition to } \\
\text { support international social entrepreneurs }\end{array}$ & 3 \\
\hline & $\begin{array}{l}\text { Purchases certified humane cage-free } \\
\text { eggs }\end{array}$ & 9 & $\begin{array}{l}\text { Percentage of sales of different products } \\
\text { goes to different nonprofits }\end{array}$ & 7 \\
\hline & $\begin{array}{l}\text { Purchases brownies from a bakery } \\
\text { that hires workers who face } \\
\text { employment barriers and has its own } \\
\text { foundation }\end{array}$ & 9 & $\begin{array}{l}\text { Advocated for increased wildlife } \\
\text { preservation }\end{array}$ & 4 \\
\hline & $\begin{array}{l}\text { Sources fully fair-trade certified } \\
\text { ingredients }\end{array}$ & 9 & $\begin{array}{l}\text { Advocated for increased community } \\
\text { spaces }\end{array}$ & 4 \\
\hline & Non-GMO & 10 & $\begin{array}{l}\text { Advocated for reduced corporate } \\
\text { influence in US politics }\end{array}$ & 3 \\
\hline & $\begin{array}{l}100 \% \text { clean energy in the US by } \\
2020\end{array}$ & 9 & $\begin{array}{l}\text { Helps franchises support local } \\
\text { communities }\end{array}$ & 6 \\
\hline & $\begin{array}{l}\text { Conduct life cycle analysis for their } \\
\text { products }\end{array}$ & 9 & $\begin{array}{l}\text { Community Action Team grant program } \\
\text { for employees to make a difference in } \\
\text { their communities }\end{array}$ & 5 \\
\hline
\end{tabular}




\begin{tabular}{|c|c|c|c|}
\hline $\begin{array}{l}\text { Helped develop technology to save } \\
\text { dairy farmers money and reduce } \\
\text { methane by } 50 \%\end{array}$ & 10 & Employee gift matching program & 3 \\
\hline $\begin{array}{l}\text { Worked to reduce impact of freezing } \\
\text { at convenience stores }\end{array}$ & 10 & Partnered with DREAM & 3 \\
\hline $\begin{array}{l}\text { Sources cookie dough from a b-corp } \\
\text { that hires refugees }\end{array}$ & 9 & $\begin{array}{l}\text { Partnered with various climate change } \\
\text { organizations }\end{array}$ & 4 \\
\hline $\begin{array}{l}\text { Values-led sourcing for non b-corp } \\
\text { suppliers }\end{array}$ & 9 & $\begin{array}{l}\text { Employees volunteer } 4,000+\text { hours } \\
\text { annually }\end{array}$ & 4 \\
\hline $\begin{array}{l}\text { Only sources from dairies who don't } \\
\text { use rBGH }\end{array}$ & 9 & $\begin{array}{l}\text { BICEP partnership (Business for } \\
\text { Innovative Climate and Energy Policy) }\end{array}$ & 4 \\
\hline $\begin{array}{l}\text { Producer Development Initiative to } \\
\text { help expand Fair-Trade agriculture }\end{array}$ & 9 & $\begin{array}{l}\text { Donates produce from on-site community } \\
\text { garden }\end{array}$ & 7 \\
\hline Minority sourcing initiative & 7 & $\begin{array}{l}\text { Meets with civil rights leaders to help } \\
\text { advocate social justice issues }\end{array}$ & 4 \\
\hline $\begin{array}{l}\text { Partnerships - Helps nonprofits run } \\
\text { shops to give vulnerable populations } \\
\text { job-training. }\end{array}$ & 10 & Annual franchise meeting service projects & 4 \\
\hline $\begin{array}{l}\text { Pays a livable wage instead of a } \\
\text { minimum wage }\end{array}$ & & $\begin{array}{l}\text { Has a foundation that donates } 2+\text { million } \\
\text { dollars a year. }\end{array}$ & 5 \\
\hline 2014 - reduced waste by $8.2 \%$ & 9 & Participates in climate change marches & 4 \\
\hline $\begin{array}{l}\text { Machine in the Netherlands that } \\
\text { converts ice cream waste into energy }\end{array}$ & 10 & Campaigns for voter rights & 3 \\
\hline $\begin{array}{l}\text { Boxes made of } 100 \% \text { recycled } \\
\text { material }\end{array}$ & 8 & $\begin{array}{l}\text { Partners with nonprofits that promote } \\
\text { peace }\end{array}$ & 3 \\
\hline $\begin{array}{l}\text { Cartons made of Forest Stewardship } \\
\text { Council and Rainforest Alliance } \\
\text { Certified material }\end{array}$ & 8 & & \\
\hline Recyclable drink cups in stores & 8 & & \\
\hline Unbleached paper napkins & 8 & & \\
\hline Green cleaning solutions in office & 9 & & \\
\hline $\begin{array}{l}\text { Recycled and chlorine-free office } \\
\text { paper }\end{array}$ & 8 & & \\
\hline Recyclable flooring in offices & 9 & & \\
\hline Low VOCs paint in offices & 9 & & \\
\hline Compostable dinnerware in offices & 8 & & \\
\hline $\begin{array}{l}\text { Gave trees to all employees on Arbor } \\
\text { Day }\end{array}$ & 9 & & \\
\hline $\begin{array}{l}\text { Local organic seeds given to all } \\
\text { employees }\end{array}$ & 9 & & \\
\hline
\end{tabular}




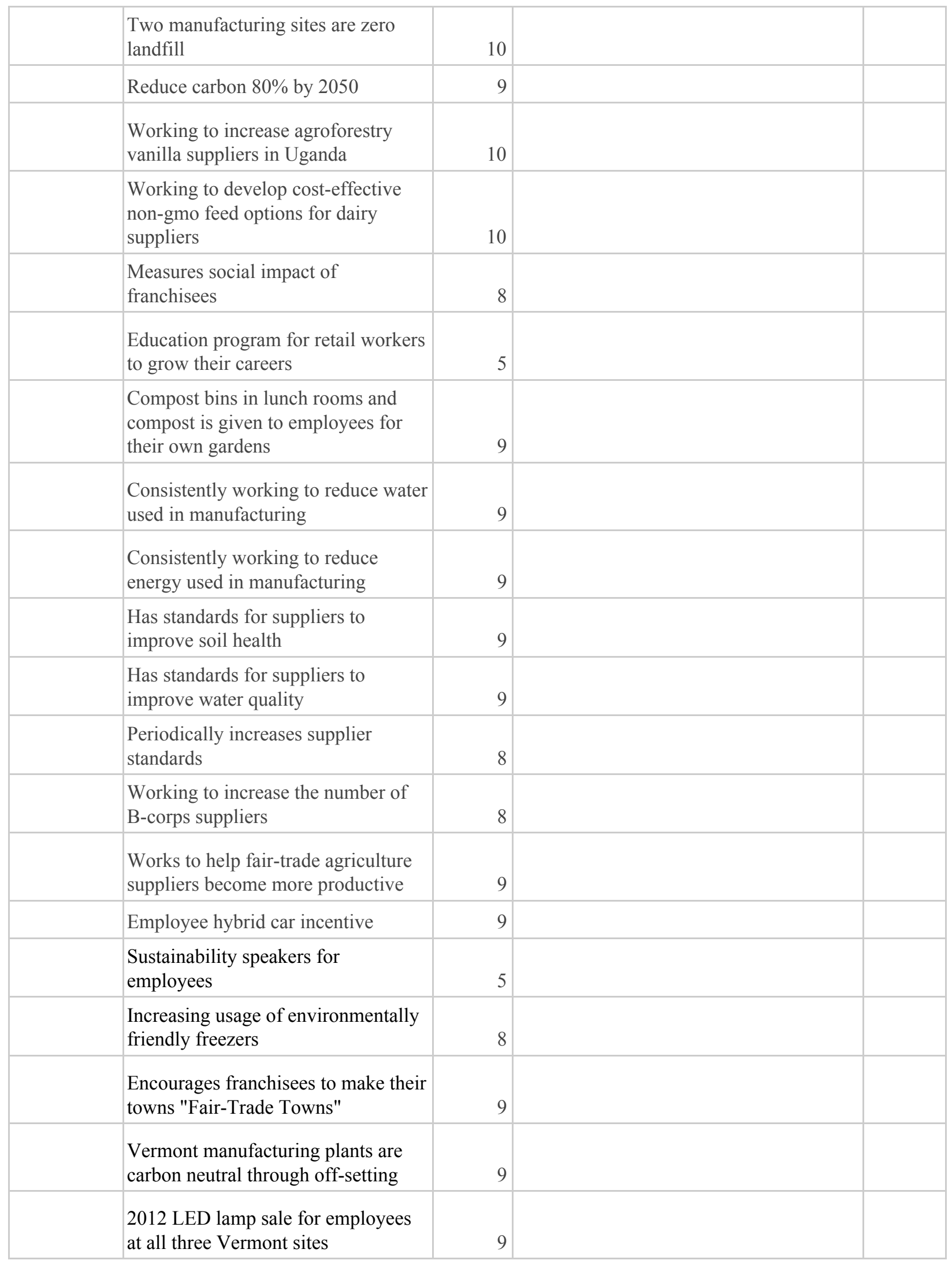


Super Stretch pallet wrap to reduce pallet wrapping material

\begin{tabular}{|c|c|c|c|c|}
\hline $\begin{array}{l}\text { AllCare } \\
\text { Health }\end{array}$ & Internal Strategies & Scores & External Strategies & Scores \\
\hline & $\begin{array}{l}\text { Continuing education programs for } \\
\text { employees }\end{array}$ & & $\begin{array}{l}\text { Trauma care and awareness training in } \\
\text { schools }\end{array}$ & 6 \\
\hline & Help senior patients heat their homes & & $\begin{array}{l}\text { Works with community agencies to } \\
\text { develop affordable housing plans }\end{array}$ & 6 \\
\hline & $\begin{array}{l}\text { Provides transportation for } \\
\text { struggling families }\end{array}$ & 9 & Donates to support community farms & 6 \\
\hline & $\begin{array}{l}\text { Helps patients get medical } \\
\text { equipment they otherwise could not } \\
\text { afford }\end{array}$ & 9 & Employee volunteer program & 4 \\
\hline & $\begin{array}{l}\text { Provides oral health screenings } \\
\text { during normal visits }\end{array}$ & 9 & Donates to support school youth programs & 5 \\
\hline & $\begin{array}{l}\text { Store that supports pregnant women } \\
\text { and gives discounts in exchange for } \\
\text { them learning how to take better care } \\
\text { of themselves and their babies }\end{array}$ & 7 & Funds childhood oral care training & 6 \\
\hline & $\begin{array}{l}\text { Retreats for addicts and the mentally } \\
\text { ill }\end{array}$ & 8 & Donated to $50+$ community programs & 5 \\
\hline & LED lights & 6 & & \\
\hline & Energy management system & 7 & & \\
\hline & $\begin{array}{l}\text { Low-flow and water conserving } \\
\text { fixtures }\end{array}$ & 6 & & \\
\hline & $\begin{array}{l}\text { Smart HVAC system that only uses } \\
\text { air when needed and prioritizes } \\
\text { outside air }\end{array}$ & 7 & & \\
\hline & $\begin{array}{l}\text { Local, reclaimed materials used to } \\
\text { construct headquarters }\end{array}$ & 7 & & \\
\hline & Drip irrigation system & 6 & & \\
\hline & $\begin{array}{l}\text { Headquarter landscape designed } \\
\text { using native plants }\end{array}$ & 6 & & \\
\hline & Prioritizes local suppliers & 7 & & \\
\hline & Gym memberships for patients & 7 & & \\
\hline & $\begin{array}{l}\text { Free transportation for patients to get } \\
\text { to the gym }\end{array}$ & 9 & & \\
\hline $\begin{array}{l}\text { New } \\
\text { Seasons } \\
\text { Market }\end{array}$ & Internal Strategies & Scores & External Strategies & Scores \\
\hline
\end{tabular}




\begin{tabular}{|c|c|c|c|}
\hline $\begin{array}{l}\text { Striving to increase management } \\
\text { diversity }\end{array}$ & 5 & $\begin{array}{l}\text { Partnered with a variety of } \\
\text { diversity-oriented organizations }\end{array}$ & 4 \\
\hline Gives managers diversity training & 6 & $\begin{array}{l}\text { Cans for Kids - Collects cans and donates } \\
\text { refunds to schools }\end{array}$ & 6 \\
\hline Over $50 \%$ of managers are females & & $\begin{array}{l}\text { Gives customers the opportunity donate } \\
\text { their reusable bag discount to a choice of } \\
\text { charities }\end{array}$ & 6 \\
\hline $\begin{array}{l}\text { Offers customers a discount for } \\
\text { using a reusable bag }\end{array}$ & & $\begin{array}{l}10 \% \text { after-tax profits is donated to the } \\
\text { community }\end{array}$ & 5 \\
\hline Striving to reduce energy usage & 7 & 944 staff members volunteered & 4 \\
\hline Striving to reduce water usage & 7 & Advocates for affordable housing & 4 \\
\hline $\begin{array}{l}\text { Installed doors on } 80 \% \text { of } \\
\text { refrigerated cases }\end{array}$ & 7 & $\begin{array}{l}\text { Advocates for increasing the minimum } \\
\text { wage }\end{array}$ & 4 \\
\hline Diverted $84 \%$ of waste from landfills & 8 & $\begin{array}{l}\text { Advocates for Oregon Outdoor School for } \\
\text { youth }\end{array}$ & 5 \\
\hline $\begin{array}{l}\text { Donates unsold food to prevent } \\
\text { waste }\end{array}$ & 7 & $\begin{array}{l}\text { Offers lots of free classes for the } \\
\text { community }\end{array}$ & 8 \\
\hline Reuses vendor containers & 8 & Hosts an annual bike fair & 6 \\
\hline $\begin{array}{l}\text { Collects difficult to recycle items } \\
\text { from customers }\end{array}$ & 8 & & \\
\hline $\begin{array}{l}\text { Partnered with a fellow b-corp for } \\
\text { cost-effective distribution of local } \\
\text { goods to stores }\end{array}$ & 8 & & \\
\hline $\begin{array}{l}\text { Use bicycles to deliver some goods } \\
\text { to their stores. }\end{array}$ & 8 & & \\
\hline $\begin{array}{l}\text { Employees serve on "Green Teams" } \\
\text { to reduce environmental impact in } \\
\text { stores }\end{array}$ & 8 & & \\
\hline $\begin{array}{l}\text { Uses a third party company to do } \\
\text { their environmental sustainability } \\
\text { audits }\end{array}$ & 6 & & \\
\hline $\begin{array}{l}\text { Some locations built with low VOC } \\
\text { paint }\end{array}$ & 8 & & \\
\hline $\begin{array}{l}\text { Some locations built with } \\
\text { post-consumer construction materials }\end{array}$ & 8 & & \\
\hline Prioritizes fair-trade products & 8 & & \\
\hline $\begin{array}{l}\text { Prioritizes suppliers who have } \\
\text { programs to support their workers } \\
\text { (ex. bananas from a cooperative of } \\
\text { banana workers instead of being } \\
\text { owned by a big corp) }\end{array}$ & 9 & & \\
\hline $\begin{array}{l}\text { Offers an abundance of organic } \\
\text { goods }\end{array}$ & 8 & & \\
\hline
\end{tabular}




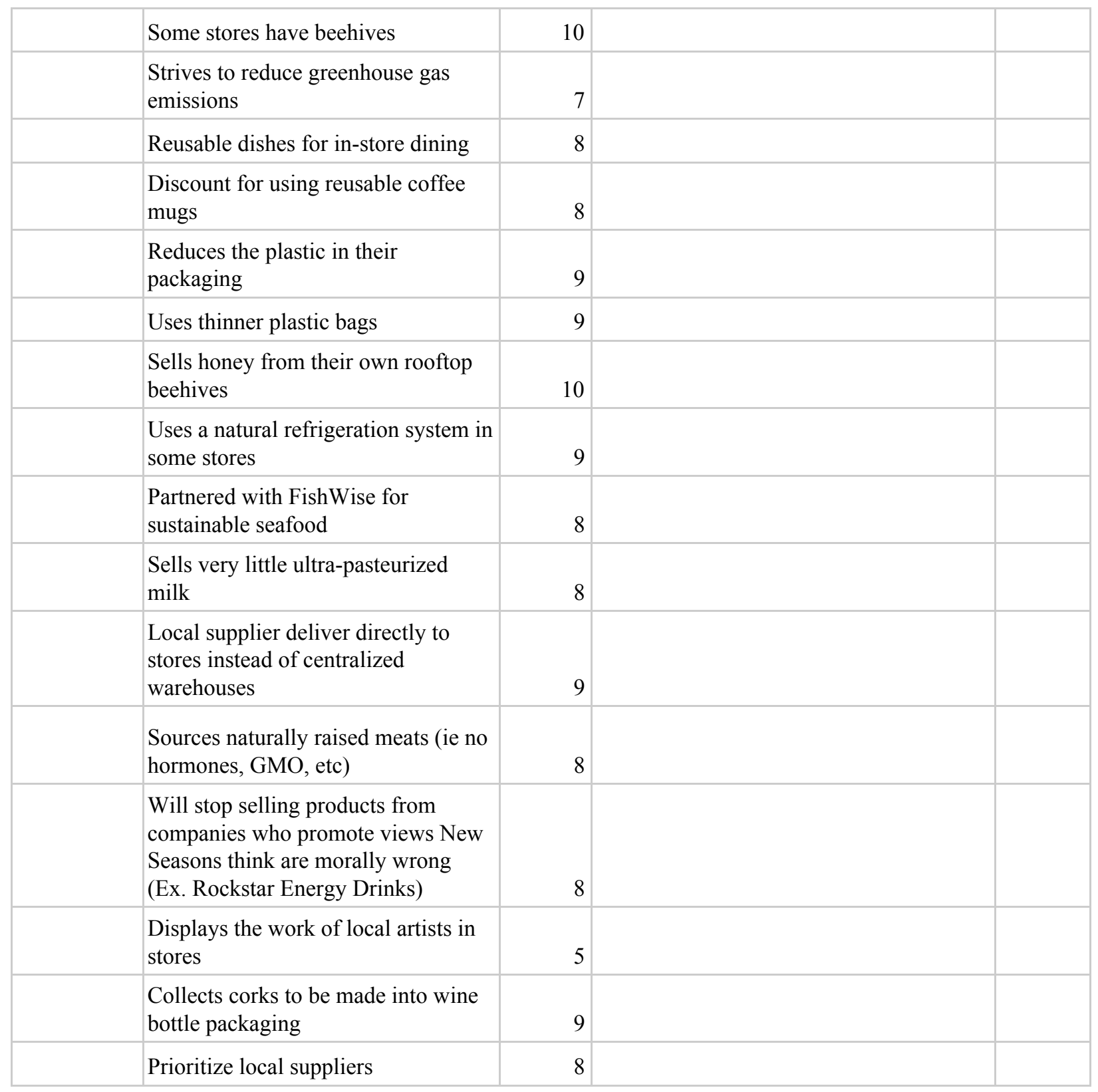

Seventh Generation

\begin{tabular}{|l|r|l|l|}
\hline Internal Strategies & Scores & External Strategies & Scores \\
\hline $\begin{array}{l}\text { Sustainability strategy is informed by } \\
\text { stakeholders, including via an annual meeting } \\
\text { with NGOs and other key stakeholders }\end{array}$ & 8 & Member of BICEP & \\
\hline $100 \%$ sustainably sourced palm oil & 8 & Advocates for climate change policies & 6 \\
\hline $\begin{array}{l}\text { Majority Forest Stewardship Council certified } \\
\text { paper products }\end{array}$ & 8 & $\begin{array}{l}\text { Advocates for ingredient labeling on } \\
\text { products }\end{array}$ & 6 \\
\hline
\end{tabular}


Conducted water scarcity assessment at manufacturing locations

$81 \%$ bio-based or recycled packaging as of 2015 (inputs)

$81 \%$ bio-based or recycled packaging as of 2015 (outputs)

Developed sustainable, non-synthetic fragrances

Uses "Safer Products" labels on applicable products

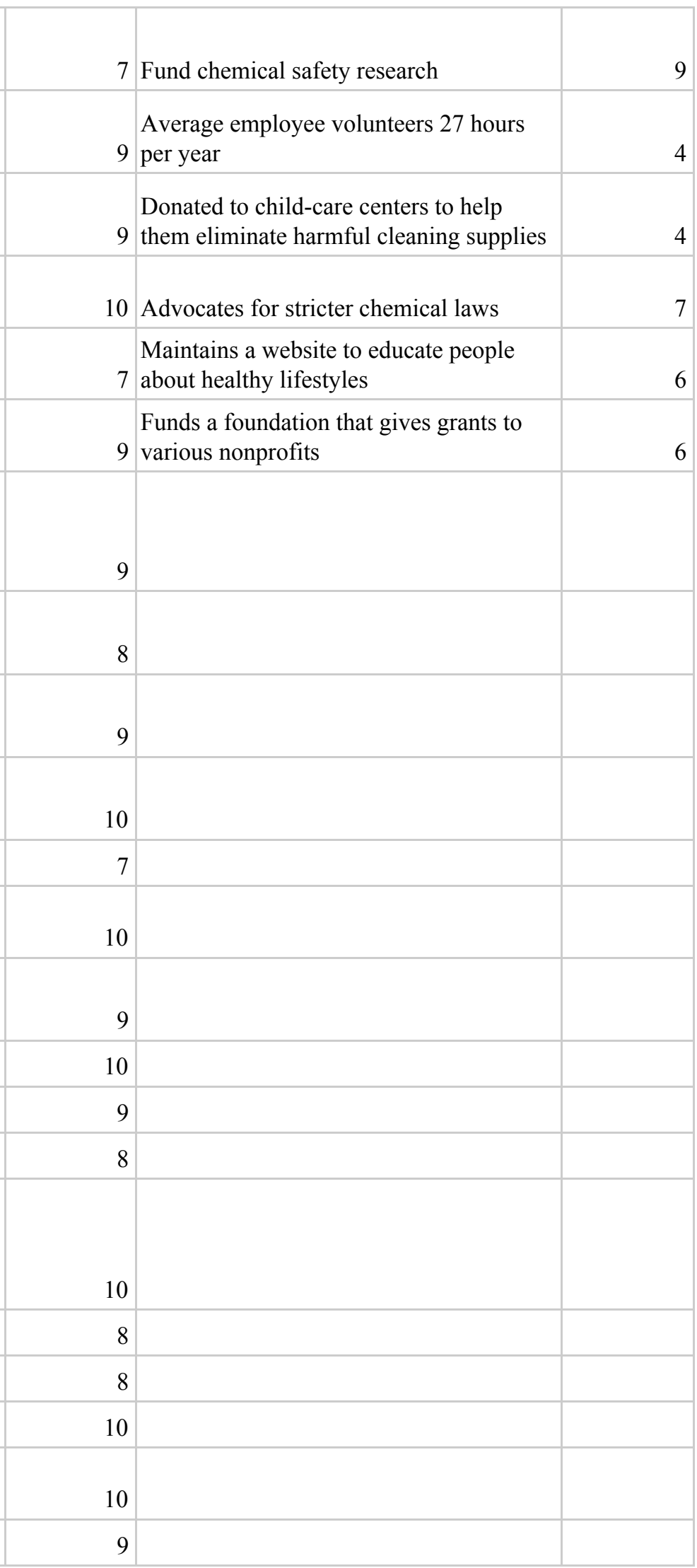

All product ingredients posted on label 


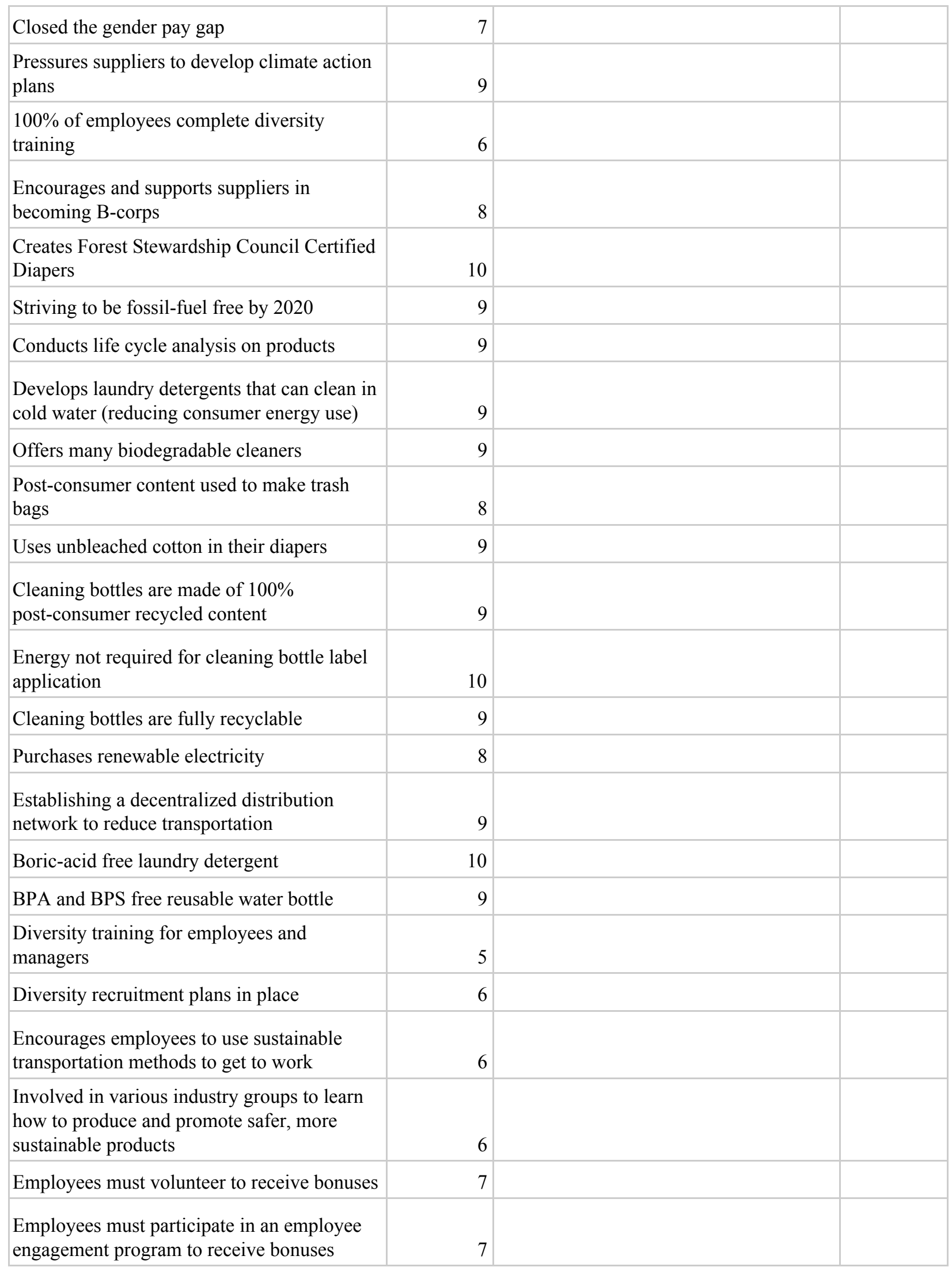




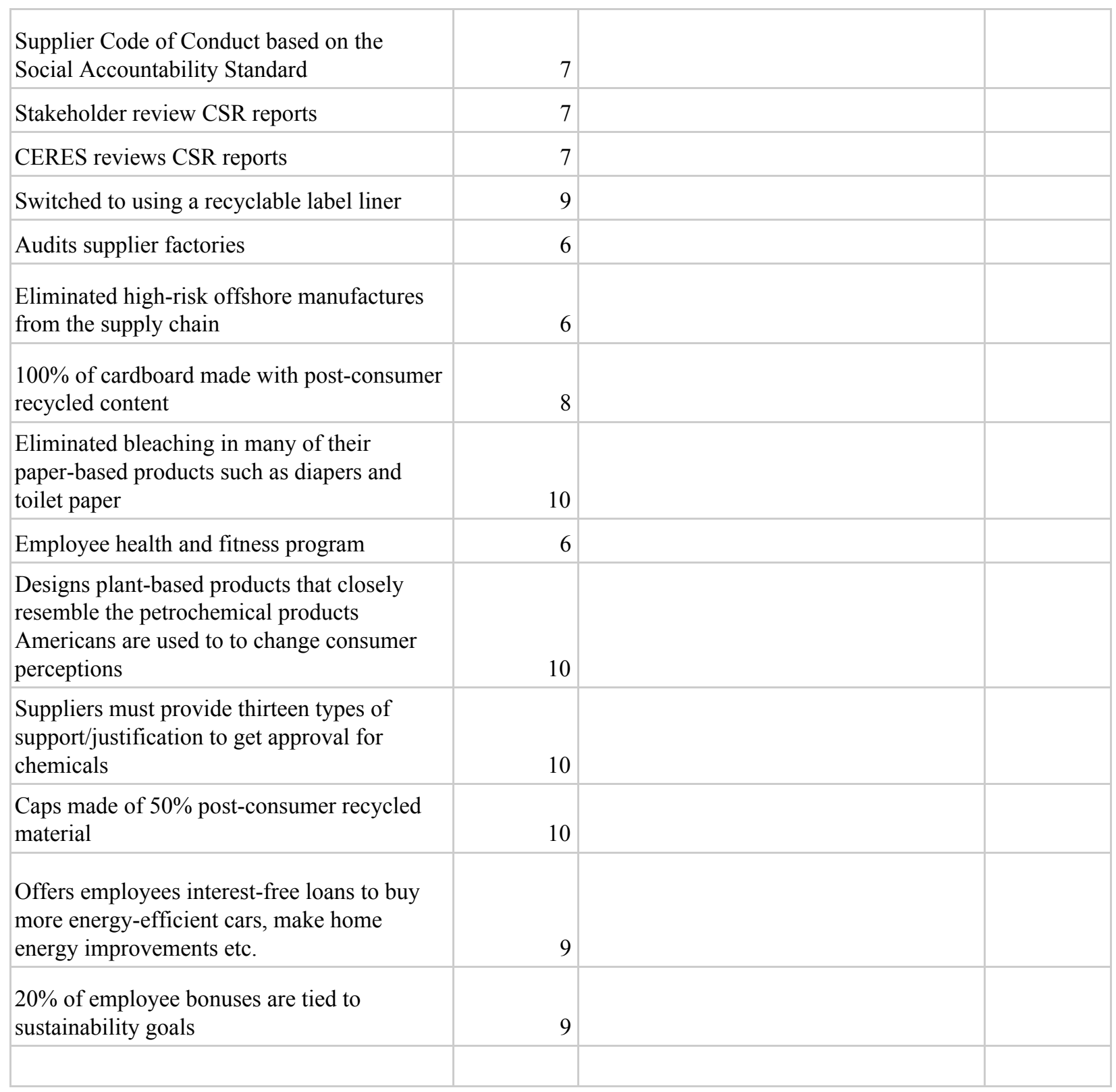

